\title{
Synthesis and Structural Analysis of Novel Norspermidine Derivatives
}

\author{
Bogumił Brycki1 ${ }^{*}$, Iwona Kowalczyk ${ }^{1}$, Justyna Werner ${ }^{1,2}$, Tomasz Pospieszny ${ }^{1}$, Anna Koziróg3 \\ ${ }^{1}$ Laboratory of Microbiocides Chemistry, Faculty of Chemistry, Adam Mickiewicz University, Poznań, Poland \\ ${ }^{2}$ Insitute of Chemistry and Technical Electrochemistry, Poznan University of Technology, Poznań, Poland \\ ${ }^{3}$ Institute of Fermentation Technology and Microbiology, Faculty of Biotechnology and Food Sciences, Lodz University of \\ Technology, Łódź, Poland \\ Email: ^brycki@amu.edu.pl
}

How to cite this paper: Brycki, B., Kowalczyk, I., Werner, J., Pospieszny, T. and Koziróg, A. (2017) Synthesis and Structural Analysis of Novel Norspermidine Derivatives. International Journal of Organic Chemistry, 7, 106-139.

https://doi.org/10.4236/ijoc.2017.72010

Received: February 1, 2017

Accepted: June 5, 2017

Published: June 8, 2017

Copyright $\odot 2017$ by authors and Scientific Research Publishing Inc. This work is licensed under the Creative Commons Attribution International License (CC BY 4.0).

http://creativecommons.org/licenses/by/4.0/

\begin{abstract}
A series of new norspermidine derivatives, both nonionic and cationic, have been obtained. Structures of the synthesized compounds have been established by FTIR, ${ }^{1} \mathrm{H}$ NMR, ${ }^{13} \mathrm{C}$ NMR, 2D NMR, mass spectrometry and elemental analyses. Physicochemical and antimicrobial properties have been discussed.
\end{abstract}

\section{Keywords}

Polyamines, Norspermidine, Phthalimides, Quaternary Ammonium Salts, Antimicrobial Activity, FTIR, ${ }^{1} \mathrm{H}$ NMR, ${ }^{13} \mathrm{CNMR}, 2 \mathrm{D}$ NMR, MS

\section{Introduction}

The chemistry of poly alkylamines is of particular interest due to its physiological significance and a wide biochemical, medical and technical applications. The history of the polyamines began in 1678 with the discovery by Leeuwenhoek of the crystallization of spermine from human semen [1]. Polyamines are ubiquitous in nature where play an important role in a cell growth and differentiation [2] [3] [4]. At a physiological $\mathrm{pH}$ the naturally occurring polyamines, spermidine $\left(\mathrm{H}_{2} \mathrm{~N}\left(\mathrm{CH}_{2}\right)_{3} \mathrm{NH}\left(\mathrm{CH}_{2}\right)_{4} \mathrm{NH}_{2}\right)$, spermine $\left(\mathrm{H}_{2} \mathrm{~N}\left(\mathrm{CH}_{2}\right)_{3} \mathrm{NH}\left(\mathrm{CH}_{2}\right)_{4} \mathrm{NH}\left(\mathrm{CH}_{2}\right)_{3} \mathrm{NH}_{2}\right)$ and their diamine precursor putrescine $\left(\mathrm{H}_{2} \mathrm{~N}\left(\mathrm{CH}_{2}\right)_{4} \mathrm{NH}_{2}\right)$, are positively charged, and interact with nucleic acids, proteins and phospholipides, affecting their structure and function [5]. For example spermine molecules occupy the small groove in DNA and neutralize two phosphate groups in each strand, thereby stabilizing the double helix by binding its two strands together. Whereas the asymmetrical polyamine, spermidine, is widespread in living organisms, the shorter symme- 
trical version, norspermidine $\left(\mathrm{H}_{2} \mathrm{~N}\left(\mathrm{CH}_{2}\right)_{3} \mathrm{NH}\left(\mathrm{CH}_{2}\right)_{3} \mathrm{NH}_{2}\right)$, is limited mainly to Vibrio species and extreme hyperthermophiles [6] in spite of this norspermidine plays an important role in a biofilm formation and biofilm degradation. Biofilms are multicellular communities of bacteria encased in an extracellular matrix of exopolysachariade, protein and sometime extracellular nucleic acids [7]. It can be formed everywhere; on biotic and abiotic surfaces [8]. Biofilms allow ofpathogens to subvert innate immune defenses what are extremely dangerous in post-antibiotic era. Similarly, biofilms in the pharmaceutical or food industry can contaminate products. Biofilms are very hard to be removed from any environment because they are resistant to antimicrobial agents and to host immune response [9]. Therefore there is a strong necessity to study of a new solution to avoid a risk of biofilm formation in hospitals as well as in pharmaceutical and food industry [7]. Some of new ideas to fight biofilms are based on norspermidine. It has been shown that norspermidine is a strong inhibitor of biofilm formed by Bacillus subtilis NCBI3610, Staphylococcus aureus SC01, Escherichia coli MC4100, Staphylococcus epidermidis. Norspermidine uniquely and directly interacts with exopolysaccharides in biofilms and reduces exopolysaccharides content, which damages biofilm matrix and makes it become loose. A part of bacteria are then released from the EPS matrix and reverted to planktonic cells, which show more sensitivity to silver ion or other microbiocides treatment than biofilm [10] [11] [12].

However, it must be also noted that norspermidine can promote biofilm formation in case of Vibrio cholerae [13]. The ambiwalent character of norspermidine towards inhibition or formation of biofilms is the subject of a vigorous dispute in the literature [6] [7] [14]-[21].

Lipophilic norspermidine derivatives as antibacterial agents also offer hope as potential solution to the problem of bacterial resistance as the membrane-active nature imparts low propensity for the development of resistance [20]. Phenylalanine conjugated aliphatic norspermidine derivatives, as membrane active antimicrobial agents, displayed improved antibacterial activity compared to nonconjugated aliphatic norspermidine derivatives. Some derivatives with dodecanoyl substituent showed over 250-fold more antimicrobial activity against VRE compared to vancomycin, last resort antibiotic for Gram-positive bacterial infection [20]. These compounds primarily damage bacterial cell membrane and kill the bacteria very quickly, below $15 \mathrm{~min}$. Moreover, bacteria do not develop resistance against them. Hence, these compounds have immense potential to be developed as therapeutic agents in order to tackle multidrug resistant bacterial infection [20].

Norspermidine and its $\mathrm{Pd}(\mathrm{II})$ and $\mathrm{Pt}(\mathrm{II})$ polynuclear complexes play also an important role as strong potential antineoplastic agents against breast cancer which is a complex disease that affect statistically one in ten women. The $\mathrm{Pd}(\mathrm{II})$ complex was shown to have strong antiproliterative effects, much stronger then that with the $\mathrm{Pt}(\mathrm{II})$ complex. Moreover, this complex is characterized as low toxic [5]. 
The very high potential of norspermidine derivatives as biofilm inhibitors, anticancer and antimicrobial agents promote us to synthesize new nonionic and cationic alkyl and phthalimide derivatives of norspermidine to study their biological effectiveness to destroy the planctonic forms of bacteria as well as bacteria biofilms.

In this work we report the results of synthetic and spectroscopic (FTIR, ${ }^{1} \mathrm{H}$ NMR, ${ }^{13} \mathrm{C}$ NMR, 2D NMR, MS) study of novel norspermidine derivatives, i.e. $N, N$-bis-(phthalimidopropyl)- $N$-alkylamines and their hydrochlorides, $N, N$-bis(phthalimidopropyl)- $N, N$-dialkylammonium iodides and $N, N$-bis-(3-aminopropyl)- $N, N$-dialkylammonium iodides.

\section{Materials and Methods}

\subsection{Chemistry}

The NMR spectra were measured with a Varian Gemini 300VT spectrometer, operating at 300.07 and $75.4614 \mathrm{MHz}$ for ${ }^{1} \mathrm{H}$ and ${ }^{13} \mathrm{C}$, respectively. Typical conditions for the proton spectra were: pulse width $32^{\circ}$, acquisition time 5 s, FT size $32 \mathrm{~K}$ and digital resolution $0.3 \mathrm{~Hz}$ per point, and for the carbon spectra pulse width $60^{\circ}$, FT size $60 \mathrm{~K}$ and digital resolution $0.6 \mathrm{~Hz}$ per point, the number of scans varied from 1200 to 10,000 per spectrum. The ${ }^{13} \mathrm{C}$ and ${ }^{1} \mathrm{H}$ chemical shifts were measured in $\mathrm{CDCl}_{3}$ and in $\mathrm{D}_{2} \mathrm{O}$ relative to an internal standard of TMS. All proton and carbon-13 resonances were assigned by ${ }^{1} \mathrm{H}$ (COSY) and ${ }^{13} \mathrm{C}$ (HETCOR). All 2D NMR spectra were recorded at $298 \mathrm{~K}$ on a Bruker Avance DRX 600 spectrometer operating at the frequencies $600.315 \mathrm{MHz}\left({ }^{1} \mathrm{H}\right)$ and $150.963 \mathrm{MHz}\left({ }^{13} \mathrm{C}\right)$, and equipped with a $5 \mathrm{~mm}$ triple-resonance inverse probehead $\left[{ }^{1} \mathrm{H} /{ }^{31} \mathrm{P} / \mathrm{BB}\right]$ with a self-shielded $\mathrm{z}$ gradient coil $\left(90^{\circ} \mathrm{H}\right.$ pulse width $9.0 \mu \mathrm{s}$ and ${ }^{13} \mathrm{C}$ pulse width $13.3 \mu$ s). Infrared spectra were recorded in the $\mathrm{KBr}$ pellets using a FT-IR Bruker IFS 66 spectrometer (Karlsruhe, Germany). The EI (electron spray ionization) mass spectra were recorded on a Waters/Micromass (Manchester, UK) ZQ mass spectrometer equipped with a Harvard Apparatus syringe pump. The sample solutions were prepared in methanol at the concentration of approximately $10^{-5} \mathrm{M}$. The standard EI-MS mass spectra were recorded at the cone voltage $30 \mathrm{~V}$.

\subsection{Synthesis.}

$\mathrm{N}, \mathrm{N}$-bis-(phthalimidopropyl)amine (A). A solution of $\mathrm{N}, \mathrm{N}$-bis-(3-aminopropyl)amine $(20 \mathrm{~mL}, 0.14 \mathrm{~mol})$ and phthalic anhydride (46 g, $0.31 \mathrm{~mol})$ in $250 \mathrm{~mL}$ of acetic acid was refluxed for 1 hour with stirring and evaporated in vacuo [22] [23] [24]. The residue was extracted with $\mathrm{CHCl}_{3}(2 \times 200 \mathrm{~mL})$ and $4 \mathrm{~N} \mathrm{NH}_{3}(200$ $\mathrm{mL}$ ) and the combined $\mathrm{CHCl}_{3}$ extract was filtered and evaporated. $\mathrm{N}, \mathrm{N}$-bis(phthalimidopropyl)amine was recrystalized from ethanol: yield 88\%; m.p. $130^{\circ} \mathrm{C}-132^{\circ} \mathrm{C}$, elemental analysis: C $67.55 \%, \mathrm{H} 5.40 \%$, N $10.77 \%$ (calcd. C $67.51 \%$, H 5.41\%, N 10.74\%).

$N, N$-bis-(phthalimidopropyl)- $N$-alkylamine (B1-B11) To 0.02 mole (7.83 
g) of $N, N$-bis-(phthalimidopropyl)amine (A) dissolved in $300 \mathrm{~mL}$ of anhydrous ethanol was added $0.025 \mathrm{~mol}$ of alkyl bromide respectively $\left[\mathrm{C}_{2} \mathrm{H}_{5} \mathrm{Br}(2.72 \mathrm{~g})\right.$, $\mathrm{C}_{3} \mathrm{H}_{7} \mathrm{Br}$ (3.07 g), $\mathrm{C}_{4} \mathrm{H}_{9} \mathrm{Br}$ (3.43 g), $\mathrm{C}_{5} \mathrm{H}_{11} \mathrm{Br}$ (3.78 g), $\mathrm{C}_{6} \mathrm{H}_{13} \mathrm{Br}(4.13 \mathrm{~g}), \mathrm{C}_{8} \mathrm{H}_{17} \mathrm{Br}$ (4.83 g), $\mathrm{C}_{10} \mathrm{H}_{21} \mathrm{Br}(5.53 \mathrm{~g}), \mathrm{C}_{12} \mathrm{H}_{25} \mathrm{Br}(6.23 \mathrm{~g}) \mathrm{C}_{14} \mathrm{H}_{29} \mathrm{Br}(6.93 \mathrm{~g}), \mathrm{C}_{16} \mathrm{H}_{33} \mathrm{Br}$ (7.63 g), $\left.\mathrm{C}_{18} \mathrm{H}_{37} \mathrm{Br}(8.33 \mathrm{~g})\right]$ and $0.02 \mathrm{~mol}(11.40 \mathrm{~g})$ anhydrous sodium carbonate. The mixture was heated at reflux for 18 - 36 hours, depending on the alkyl chain length of the substrate used, preventing the reaction mixture from moisture. After filtering off the sodium carbonate and the solvent evaporated in vacuo to dryness, the products was crystallized from anhydrous ethanol: $\mathrm{B} 1: \mathrm{R}=\mathrm{C}_{2} \mathrm{H}_{5^{-}}$, yield $88 \%$; m.p. $122^{\circ} \mathrm{C}-124^{\circ} \mathrm{C}$, elemental analysis: C 68.58\%, H 5.92\%, N 10.17\% (calcd. C 68.72\%, H 6.01\%, N 10.02\%); B2: $\mathrm{R}=\mathrm{C}_{3} \mathrm{H}_{7^{-}}$, yield 90\%; m.p. $109^{\circ} \mathrm{C}-$ $111^{\circ} \mathrm{C}$, elemental analysis: C 69.20\%, H 6.31\%, N 9.71\% (calcd. C 69.27\%, H 6.28\%, $\mathrm{N}$ 9.69\%); B3: $\mathrm{R}=\mathrm{C}_{4} \mathrm{H}_{9^{-}}$, yield 73\%; m.p. $106^{\circ} \mathrm{C}-108^{\circ} \mathrm{C}$, elemental analysis: C 69.67\%, H 6.42\%, N 9.44\% (calcd. C 69.78\%, H 6.53\%, N 9.39\%); B4: R = $\mathrm{C}_{5} \mathrm{H}_{11^{-}}$, yield $78 \%$; m.p. $100-102^{\circ} \mathrm{C}$, elemental analysis: $\mathrm{C} 70.12 \%, \mathrm{H} 6.70 \%, \mathrm{~N}$ 9.02\% (calcd. C 70.26\%, H 6.77\%, N 9.10\%); B5: $\mathrm{R}=\mathrm{C}_{6} \mathrm{H}_{13^{-}}$, yield 72\%; m.p. $95^{\circ} \mathrm{C}-98^{\circ} \mathrm{C}$, elemental analysis: C 70.58\%, H 7.23\%, N 8.73\% (calcd. C 70.71\%, $\mathrm{H} 6.99 \%, \mathrm{~N} 8.84 \%$ ); B6: $\mathrm{R}=\mathrm{C}_{8} \mathrm{H}_{17^{-}}$, yield 70\%; m.p. $89^{\circ} \mathrm{C}-91^{\circ} \mathrm{C}$, elemental analysis: C 71.43\%, H 7.52\%, N 8.29\% (calcd. C 71.54\%, H 7.40\%, N 8.34\%); B7: $\mathrm{R}=\mathrm{C}_{10} \mathrm{H}_{21^{-}}$, yield $71 \%$; m.p. $76^{\circ} \mathrm{C}-78^{\circ} \mathrm{C}$, elemental analysis: $\mathrm{C} 72.39 \%, \mathrm{H} 7.63 \%$, N 7.99\% (calcd. C 72.29\%, H 7.77\%, N 7.90\%); B8: $\mathrm{R}=\mathrm{C}_{12} \mathrm{H}_{25}$, yield 70\%; m.p. $68^{\circ} \mathrm{C}-69^{\circ} \mathrm{C}$, elemental analysis: C 73.12\%, H 8.10\%, N 7.55\% (calcd. C 72.96\%, $\mathrm{H} 8.10 \%, \mathrm{~N} 7.51 \%$ ); B9: $\mathrm{R}=\mathrm{C}_{14} \mathrm{H}_{29^{-}}$, yield 78\%; m.p. $59^{\circ} \mathrm{C}-60^{\circ} \mathrm{C}$, elemental analysis: C 73.41\%, H 8.98\%, N 7.25\% (calcd. C 73.56\%, H 8.40\%, N 7.15\%); B10: $\mathrm{R}=\mathrm{C}_{16} \mathrm{H}_{33}-$, yield $70 \%$; m.p. $56^{\circ} \mathrm{C}-57^{\circ} \mathrm{C}$, elemental analysis: $\mathrm{C} 74.17 \%, \mathrm{H}$ 8.37\%, N 6.89\% (calcd. C 74.11\%, H 8.67\%, N 6.82\%); B11: $\mathrm{R}=\mathrm{C}_{18} \mathrm{H}_{37^{-}}$, yield $73 \%$; m.p. $52^{\circ} \mathrm{C}-53^{\circ} \mathrm{C}$, elemental analysis: C 74.77\%, H 9.17\%, N 6.25\% (calcd. C 74.61\%, H 8.92\%, N 6.53\%).

$N, N, N$-tris-(phthalimidopropyl)amine (B12) To 0.02 mole $(7.83 \mathrm{~g})$ of $N, N$ bis-(phthalimidopropyl)amine (A) dissolved in $300 \mathrm{~mL}$ of anhydrous ethanol was added 0.025 mole $(6.70 \mathrm{~g})$ phthalimide bromide and $0.02 \mathrm{~mol}(11.40 \mathrm{~g})$ of anhydrous sodium carbonate. The mixture was heated under reflux for 18 hours, protecting the reaction mixture from moisture. After filtering off the sodium carbonate and the solvent evaporated in vacuo to dryness, the resulting $N, N, N$ tris-(phthalimidopropyl)amine (B12) was crystallized from absolute ethanol: yield $90 \%, \mathrm{mp} 138^{\circ} \mathrm{C}-140^{\circ} \mathrm{C}$, elemental analysis: C 68.43\%, H 5.36\%, N 9.67\% (calcd. C 68.50\%, H 5.23\%, N 9.68\%).

$N, N$-bis-(phthalimidopropyl)amine hydrochloride (C) To $0.025 \mathrm{~mol}$ (10.70 g) of $N, N$-bis-(phthalimidopropyl)amine (A) dissolved in $30 \mathrm{~mL}$ of methanol was added 0.025 mole $(2.53 \mathrm{~g}$ ) of concentrated $\mathrm{HCl}$ dissolved in $15 \mathrm{~mL}$ of methanol. The solution was stirred for 20 minutes at $20^{\circ} \mathrm{C}$, and then evaporated under reduced pressure to dryness. The resulting hydrochloride salt of $N, N$-bis(phthalimidopropyl)amine (C) was crystallized from absolute ethanol: yield 98\%, m.p. $183^{\circ} \mathrm{C}-185^{\circ} \mathrm{C}$, elemental analysis: C $61.59 \%, \mathrm{H} 5.38 \%, \mathrm{~N} 9.50 \%$ (calcd. C 
91.75\%, H 5.18\%, N 9.82\%).

$N, N$-bis-(phthalimidopyl)- $N$-alkylamines hydrochlorides (D1-D11) Corresponding to 0.025 moles of $N, N$-bis-(phthalimidopropyl)-N-alkylamine (B1B11) [alkyl $=\mathrm{C}_{2} \mathrm{H}_{5^{-}}$(10.49 g), $\mathrm{C}_{3} \mathrm{H}_{7^{-}}(10.84 \mathrm{~g}), \mathrm{C}_{4} \mathrm{H}_{9^{-}}(11.19 \mathrm{~g}), \mathrm{C}_{5} \mathrm{H}_{11^{-}}(11.54 \mathrm{~g})$, $\mathrm{C}_{6} \mathrm{H}_{13^{-}}(11.89 \mathrm{~g}), \mathrm{C}_{8} \mathrm{H}_{17^{-}}(12.59 \mathrm{~g}), \mathrm{C}_{10} \mathrm{H}_{21^{-}}(13.29 \mathrm{~g}), \mathrm{C}_{12} \mathrm{H}_{25^{-}}$(13.99 g), $\mathrm{C}_{14} \mathrm{H}_{29^{-}}$ $\left.(14.70 \mathrm{~g}), \mathrm{C}_{16} \mathrm{H}_{33^{-}}(15.40 \mathrm{~g}), \mathrm{C}_{18} \mathrm{H}_{37^{-}}(16.10 \mathrm{~g})\right]$ dissolved in $30 \mathrm{~mL}$ of methanol was added 0.025 mole $(2.53 \mathrm{~g})$ of concentrated $\mathrm{HCl}$ dissolved in $15 \mathrm{~mL}$ of methanol. The solution was stirred for 20 minutes at $20^{\circ} \mathrm{C}$, and then evaporated under reduced pressure to dryness. The resulting product was crystallized from absolute ethanol. D1: $\mathrm{R}=\mathrm{C}_{2} \mathrm{H}_{5^{-}}$, yield $80 \%$; m.p. $148^{\circ} \mathrm{C}-149^{\circ} \mathrm{C}$, elemental analysis: C 63.37\%, H 5.88\%, N 9.07\% (calcd. C 63.22\%, H 5.75\%, N 9.22\%); D2: R = $\mathrm{C}_{3} \mathrm{H}_{7^{-}}$, yield $83 \%$; m.p. $140^{\circ} \mathrm{C}-142^{\circ} \mathrm{C}$, elemental analysis: $\mathrm{C} 63.84 \%, \mathrm{H} 6.08 \%, \mathrm{~N}$ 8.93\% (calcd. C 63.89\%, H 6.01\%, N 8.94\%);D3: $\mathrm{R}=\mathrm{C}_{4} \mathrm{H}_{9}-$, yield 77\%; m.p. $124^{\circ} \mathrm{C}-126^{\circ} \mathrm{C}$, elemental analysis: C $64.20 \%, \mathrm{H} 5.97 \%$, N $8.48 \%$ (calcd. C $64.52 \%, \mathrm{H} 6.25 \%, \mathrm{~N} 8.68 \%$ ); D4: $\mathrm{R}=\mathrm{C}_{5} \mathrm{H}_{11^{-}}$, yield 71\%; m.p. $120^{\circ} \mathrm{C}-121^{\circ} \mathrm{C}$, elemental analysis: C 65.22\%, H 6.25\%, N 8.38\% (calcd. C 65.12\%, H 6.48\%, N 8.44\%); D5: $\mathrm{R}=\mathrm{C}_{6} \mathrm{H}_{13^{3}}$, yield $74 \%$; m.p. $117^{\circ} \mathrm{C}-119^{\circ} \mathrm{C}$, elemental analysis: $\mathrm{C}$ 65.52\%, H 6.60\%, N 8.13\% (calcd. C 65.68\%, H 6.69\%, N 8.21\%); D6: $\mathrm{R}=\mathrm{C}_{8} \mathrm{H}_{17^{-}}$, yield $78 \%$; m.p. $107^{\circ} \mathrm{C}-109^{\circ} \mathrm{C}$, elemental analysis: C $66.59 \%$, H 7.21\%, N 7.68\% (calcd. C 66.71\%, H 7.09\%, N 7.78\%); D7: $\mathrm{R}=\mathrm{C}_{10} \mathrm{H}_{21^{-}}$, yield 68\%; m.p. $98-100^{\circ} \mathrm{C}$, elemental analysis: C 66.59\%, H 7.21\%, N 7.68\% (calcd. C 67.65\%, H 7.45\%, N 7.40\%); D8: $\mathrm{R}=\mathrm{C}_{12} \mathrm{H}_{25^{-}}$, yield $66 \%$; m.p. $86^{\circ} \mathrm{C}-88^{\circ} \mathrm{C}$, elemental analysis: $\mathrm{C}$ $68.42 \%, \mathrm{H} 7.63 \%$, N 7.18\% (calcd. C 68.49\%, H 7.78\%, N 7.05\%); D9: R = $\mathrm{C}_{14} \mathrm{H}_{29^{-}}$, yield $65 \%$; m.p. $78^{\circ} \mathrm{C}-80^{\circ} \mathrm{C}$, elemental analysis: $\mathrm{C} 69.47 \%, \mathrm{H} 7.92 \%$, N 6.56\% (calcd. C 69.26\%, H 8.07\%, N 6.73\%); D10: $\mathrm{R}=\mathrm{C}_{16} \mathrm{H}_{33^{-}}$, yield 72\%; m.p. $73^{\circ} \mathrm{C}-75^{\circ} \mathrm{C}$, elemental analysis: C $69.73 \%, \mathrm{H} 8.28 \%, \mathrm{~N} 6.23 \%$ (calcd. C 69.97\%, H 8.34\%, N 6.44\%); D11: $\mathrm{R}=\mathrm{C}_{18} \mathrm{H}_{37^{-}}$, yield $61 \%$; m.p. $69^{\circ} \mathrm{C}-70^{\circ} \mathrm{C}$, elemental analysis: C 70.42\%, H 8.43\%, N 5.96\% (calcd. C 70.61\%, H 8.59\%, N $6.18 \%)$.

$N, N, N$-tris-(phthalimidopropyl)amine hydrochloride (D12) To $0.025 \mathrm{~mol}$ (14.48 g) of $N, N, N$-tris-(phthalimidopropyl)amine (B12) are dissolved in $30 \mathrm{~mL}$ of methanol was added 0.025 mole $(2.53 \mathrm{~g}$ ) of concentrated $\mathrm{HCl}$ dissolved in 15 $\mathrm{mL}$ of methanol. The solution was stirred for 5 minutes at $20^{\circ} \mathrm{C}$, and then evaporated under reduced pressure to dryness. The resulting hydrochloride salt of $\mathrm{N}, \mathrm{N}, \mathrm{N}$-tris-(phthalimidopropyl)amine (D12) was crystallized from absolute ethanol: yield $94 \%$, m.p. $228^{\circ} \mathrm{C}-230^{\circ} \mathrm{C}$, elemental analysis: C $64.52 \%$, H $5.13 \%$, $\mathrm{N} 9.02 \%$ (calcd. C 64.44\%, H 5.08\%, N 9.11\%).

$\boldsymbol{N}, \boldsymbol{N}$-bis-(3-aminopropyl)- $\boldsymbol{N}$-alkylamine (E1-E6) Corresponding to 0.025 moles of $N, N$-bis-(phthalimidopropyl)- $N$-alkylamines (B2, B3, B6, B8, B10, B11) [alkyl $=\mathrm{C}_{3} \mathrm{H}_{7^{-}}(10.84 \mathrm{~g}), \mathrm{C}_{4} \mathrm{H}_{9^{-}}(11.19 \mathrm{~g}), \mathrm{C}_{8} \mathrm{H}_{17^{-}}(12.59 \mathrm{~g}), \mathrm{C}_{12} \mathrm{H}_{25^{-}}$(13.99 g), $\left.\mathrm{C}_{16} \mathrm{H}_{33^{-}}(15.40 \mathrm{~g}), \mathrm{C}_{18} \mathrm{H}_{37^{-}}(16.10 \mathrm{~g})\right]$ dissolved in $50 \mathrm{~mL}$ of anhydrous ethanol was added $0.1 \mathrm{~mol}(4.91 \mathrm{~g})$ and hydrazine monohydrate was stirred at $20^{\circ} \mathrm{C}$ for 24 hours. The white, gelatinous precipitate was filtered off and the filtrate was added to $30 \mathrm{~mL}$ of $2 \mathrm{M} \mathrm{HCl}$. After filtration of the precipitate, the solution was 
basified with 2-molar $\mathrm{NaOH}$, and then extracted with methylene chloride $(2 \times$ $100 \mathrm{~mL}$ ). The collected organic layer was dried with anhydrous potassium carbonate. After filtering off the drying agent, the solution was evaporated and the liquid residue was distilled under reduced pressure $(0.05 \mathrm{mmHg})$ to collect the fraction corresponding $N, N$-bis-(3-aminopropyl)- $N$-alkylamine (E1-E6). E1: R $=\mathrm{C}_{3} \mathrm{H}_{7^{-}}$, yield $65 \%$; b.p. $45^{\circ} \mathrm{C}-46^{\circ} \mathrm{C}$; E2: $\mathrm{R}=\mathrm{C}_{4} \mathrm{H}_{9^{-}}$, yield $54 \%$; b.p. $54^{\circ} \mathrm{C}-55^{\circ} \mathrm{C}$; E3: $\mathrm{R}=\mathrm{C}_{8} \mathrm{H}_{17^{-}}$, yield $56 \%$; b.p. $81^{\circ} \mathrm{C}-82^{\circ} \mathrm{C}$; E4: $\mathrm{R}=\mathrm{C}_{12} \mathrm{H}_{25^{-}}$, yield $55 \%$; b.p. $110^{\circ} \mathrm{C}-111^{\circ} \mathrm{C}$; E5: $\mathrm{R}=\mathrm{C}_{16} \mathrm{H}_{33^{-}}$, yield $55 \%$; b.p. $128^{\circ} \mathrm{C}-130^{\circ} \mathrm{C}$; E6: $\mathrm{R}=\mathrm{C}_{18} \mathrm{H}_{37^{-}}$, yield $48 \%$; b.p. $135^{\circ} \mathrm{C}-136^{\circ} \mathrm{C}$.

$N, N$-bis-(phthalimidopropyl)- $N, N$-dialkiloammonium iodides (F1-F17) Reactions obtaining of $N, N$-bis-(phthalimidopropyl)- $N, N$-dialkiloammonium iodides (F1-F17) was performed by two methods, depending on the alkyl chain length substrates used.

Method I. Synthesis method carried out in a solvent. To 0.1 mole of $N, N$-bis(phthalimidopropylo)- $N$-alkylamine (B2, B3, B5, B6) [alkyl- $=\mathrm{C}_{3} \mathrm{H}_{7}-(43.35 \mathrm{~g})$, $\left.\mathrm{C}_{4} \mathrm{H}_{9}-(44.75 \mathrm{~g}), \mathrm{C}_{6} \mathrm{H}_{13^{-}}(47.56 \mathrm{~g}), \mathrm{C}_{8} \mathrm{H}_{17^{-}}(50.36 \mathrm{~g})\right]$, dissolved in $50 \mathrm{~mL}$ of anhydrous ethanol was added 0.12 mole of the appropriate alkyl iodide $\left[\mathrm{C}_{2} \mathrm{H}_{5} \mathrm{I}\right.$ (18.72 g), $\mathrm{C}_{3} \mathrm{H}_{7} \mathrm{I}(20.40 \mathrm{~g}), \mathrm{C}_{4} \mathrm{H}_{9} \mathrm{I}(22.08 \mathrm{~g}), \mathrm{C}_{6} \mathrm{H}_{13} \mathrm{I}(25.45 \mathrm{~g}), \mathrm{C}_{8} \mathrm{H}_{17} \mathrm{I}$ (28.82 g), $\mathrm{C}_{10} \mathrm{H}_{21} \mathrm{I}(32.18 \mathrm{~g})$ ]. The mixture was heated under reflux for 2 - 80 hours, depending on the alkyl chain length substrates used, preventing the reaction mixture from moisture. The resulting product was filtered off, and then to remove residual reactants, washed with toluene at a temperature of $70^{\circ} \mathrm{C}-80^{\circ} \mathrm{C}$. Solid product is crystallized from a mixture of anhydrous ethanol-methanol (1:2): F1: $\mathrm{R}=\mathrm{C}_{3} \mathrm{H}_{7^{-}}, \mathrm{R}^{\prime \prime}=\mathrm{C}_{2} \mathrm{H}_{5^{-}}$, yield $85 \%$; m.p. $217^{\circ} \mathrm{C}-219^{\circ} \mathrm{C}$, elemental analysis: $\mathrm{C}$ $54.86 \%$, H 5.41\%, N 6.97\% (calcd. C 55.01\%, H 5.47\%, N 7.13\%); F2: $\mathrm{R}=\mathrm{C}_{3} \mathrm{H}_{7^{-}}$, $\mathrm{R}^{\prime \prime}=\mathrm{C}_{3} \mathrm{H}_{7^{-}}$, yield $84 \%$; m.p. $188^{\circ} \mathrm{C}-189^{\circ} \mathrm{C}$, elemental analysis: C $55.87 \%, \mathrm{H}$ $5.73 \%, \mathrm{~N} 6.82 \%$ (calcd. C 55.73\%, H 5.68\%, N 6.96\%); F3: R $=\mathrm{C}_{3} \mathrm{H}_{7^{-}}, \mathrm{R}^{\prime \prime}=$ $\mathrm{C}_{4} \mathrm{H}_{9^{-}}$, yield $86 \%$; m.p. $193^{\circ} \mathrm{C}-195^{\circ} \mathrm{C}$, elemental analysis: C $56.52 \%, \mathrm{H} 5.81 \%, \mathrm{~N}$ 6.72\% (calcd. C 56.40\%, H 5.88\%, N 6.80\%); F4: $\mathrm{R}=\mathrm{C}_{3} \mathrm{H}_{7^{-}}, \mathrm{R}^{\prime \prime}=\mathrm{C}_{6} \mathrm{H}_{13^{-}}$, yield $72 \%$; m.p. $141^{\circ} \mathrm{C}-142^{\circ} \mathrm{C}$, elemental analysis: C $56.52 \%, \mathrm{H} 6.20 \%, \mathrm{~N} 6.63 \%$ (calcd. C 57.67\%, H 6.25\%, N 6.51\%); F5: $\mathrm{R}=\mathrm{C}_{3} \mathrm{H}_{7^{-}}, \mathrm{R}^{\prime \prime}=\mathrm{C}_{8} \mathrm{H}_{17^{-}}$, yield 72\%; m.p. $120^{\circ} \mathrm{C}-122^{\circ} \mathrm{C}$, elemental analysis: C 58.79\%, H 6.51\%, N 6.29\% (calcd. C 58.84\%, H 6.58\%, N 6.24\%); F6: $\mathrm{R}=\mathrm{C}_{3} \mathrm{H}_{7^{-}}, \mathrm{R}^{\prime \prime}=\mathrm{C}_{10} \mathrm{H}_{21^{-}}$, yield 69\%; m.p. $108^{\circ} \mathrm{C}$ - $111^{\circ} \mathrm{C}$, elemental analysis: C 59.85\%, H 6.85\%, N 5.88\% (calcd. C 59.91\%, H 6.90\%, N 5.99\%); F10: $\mathrm{R}=\mathrm{C}_{4} \mathrm{H}_{9^{-}}, \mathrm{R}^{\prime \prime}=\mathrm{C}_{4} \mathrm{H}_{9^{-}}$, yield 76\%; m.p. $171^{\circ} \mathrm{C}-172^{\circ} \mathrm{C}$, elemental analysis: C 57.01\%, H 6.09\%, N 6.67\% (calcd. C 57.05\%, H 6.06\%, N 6.65\%); F11: $\mathrm{R}=\mathrm{C}_{6} \mathrm{H}_{13^{-}}, \mathrm{R}^{\prime \prime}=\mathrm{C}_{6} \mathrm{H}_{13^{-}}$, yield 69\%; m.p. $162^{\circ} \mathrm{C}-164^{\circ} \mathrm{C}$, elemental analysis: C 59.28\%, H 6.85\%, N 6.17\% (calcd. C 59.39\%, H 6.74\%, N 6.11\%); F12: $\mathrm{R}=\mathrm{C}_{8} \mathrm{H}_{17^{-}}, \mathrm{R}^{\prime \prime}=\mathrm{C}_{8} \mathrm{H}_{17^{-}}$, yield $62 \%$; m.p. $98^{\circ} \mathrm{C}-99^{\circ} \mathrm{C}$, elemental analysis: $\mathrm{C}$ $61.31 \%$, H 7.25\%, N 5.72\% (calcd. C 61.36\%, H 7.32\%, N 5.65\%).

Method II. Synthesis carried out without solvent. To 0.1 moles of molten $N, N$-bis-(phthalimidopropyl)- $N$-alkylamine (B7, B8, B10, B11) [alkyl $=\mathrm{C}_{10} \mathrm{H}_{21}{ }^{-}$ (53.17 g), $\mathrm{C}_{12} \mathrm{H}_{25^{-}}$(55.97 g), $\mathrm{C}_{16} \mathrm{H}_{33^{-}}$(61.59 g), $\left.\mathrm{C}_{18} \mathrm{H}_{37^{-}}(64.39 \mathrm{~g})\right]$ was added 0.12 mole of the appropriate alkyl iodide $\left[\mathrm{C}_{3} \mathrm{H}_{7} \mathrm{I}(20.40 \mathrm{~g}), \mathrm{C}_{8} \mathrm{H}_{17} \mathrm{I}(28.82 \mathrm{~g}), \mathrm{C}_{10} \mathrm{H}_{21} \mathrm{I}\right.$ 
(32.18 g), $\left.\mathrm{C}_{12} \mathrm{H}_{25} \mathrm{I}(35.55 \mathrm{~g}), \mathrm{C}_{18} \mathrm{H}_{37} \mathrm{I}(45.65 \mathrm{~g})\right]$. The mixture is heated at a temperature not exceeding $65^{\circ} \mathrm{C}$ for 62 - 200 hours, depending on the alkyl chain length substrates used, preventing the reaction mixture from moisture. The resulting solid product was filtered off and then washed with toluene at a temperature of $60^{\circ} \mathrm{C}-65^{\circ} \mathrm{C}$, to remove residual unreacted starting materials. The products obtained were crystallized from a mixture of anhydrous ethanol-acetone (1:2): F7: $\mathrm{R}=\mathrm{C}_{3} \mathrm{H}_{7^{-}}, \mathrm{R}^{\prime \prime}=\mathrm{C}_{12} \mathrm{H}_{25^{-}}$, yield $63 \%$; m.p. $91^{\circ} \mathrm{C}-93^{\circ} \mathrm{C}$, elemental analysis: C 60.77\%, H 7.30\%, N 5.73\% (calcd. C 60.90\%, H 7.18\%, N 5.76\%); F8: R = $\mathrm{C}_{3} \mathrm{H}_{7^{-}}, \mathrm{R}^{\prime \prime}=\mathrm{C}_{16} \mathrm{H}_{33^{-}}$, yield $65 \%$; m.p. $79^{\circ} \mathrm{C}-81^{\circ} \mathrm{C}$, elementalanalysis: $\mathrm{C} 62.58 \%$, $\mathrm{H} 7.63 \%$, N 5.41\% (calcd. C 62.66\%, H 7.70\%, N 5.35\%); F9: R = $\mathrm{C}_{3} \mathrm{H}_{7^{-}}, \mathrm{R}^{\prime}=$ $\mathrm{C}_{18} \mathrm{H}_{37^{-}}$, yield $66 \%$; m.p. $65^{\circ} \mathrm{C}-66^{\circ} \mathrm{C}$, elemental analysis: $\mathrm{C} 63.40 \%, \mathrm{H} 7.88 \%, \mathrm{~N}$ 5.23\% (calcd. C 63.46\%, H 7.93\%, N 5.16\%); F13: $\mathrm{R}=\mathrm{C}_{10} \mathrm{H}_{21^{-}}, \mathrm{R}^{\prime \prime}=\mathrm{C}_{10} \mathrm{H}_{21^{-}}$, yield $59 \%$; m.p. $74^{\circ} \mathrm{C}-76^{\circ} \mathrm{C}$, elemental analysis: C 63.07\%, H 7.77\%, N 5.29\% (calcd. C 63.07\%, H 7.81\%, N 5.25\%); F14: $\mathrm{R}=\mathrm{C}_{12} \mathrm{H}_{25^{-}}, \mathrm{R}^{\prime \prime}=\mathrm{C}_{12} \mathrm{H}_{25^{-}}$, yield 64\%; m.p. $68^{\circ} \mathrm{C}-69^{\circ} \mathrm{C}$, elemental analysis: C 64.21\%, H 8.38\%, N 4.83\% (calcd. C 64.55\%, $\mathrm{H}$ 8.24\%, N 4.91\%); F15: $\mathrm{R}=\mathrm{C}_{18} \mathrm{H}_{37^{-}}, \mathrm{R}^{\prime \prime}=\mathrm{C}_{18} \mathrm{H}_{37^{-}}$, yield $52 \%$; m.p. $51^{\circ} \mathrm{C}-53^{\circ} \mathrm{C}$, elemental analysis: C 68.09\%, H 9.19\%, N 4.16\% (calcd. C 68.01\%, H 9.25\%, N 4.10\%); F16: $\mathrm{R}=\mathrm{C}_{8} \mathrm{H}_{17^{-}}, \mathrm{R}^{\prime \prime}=\mathrm{C}_{12} \mathrm{H}_{25^{-}}$, yield $62 \%$; m.p. $69^{\circ} \mathrm{C}-70^{\circ} \mathrm{C}$, elemental analysis: C 63.20\%, H 8.02\%, N 5.18\% (calcd. C 63.07\%, H 7.81\%, N 5.25\%); F17: $\mathrm{R}=\mathrm{C}_{12} \mathrm{H}_{25^{-}}, \mathrm{R}^{\prime \prime}=\mathrm{C}_{18} \mathrm{H}_{37^{-}}$, yield $55 \%$; m.p. $70^{\circ} \mathrm{C}-72^{\circ} \mathrm{C}$, elemental analysis: $\mathrm{C}$ $66.14 \%, \mathrm{H} 8.91 \%$, N 4.44\% (calcd. C 66.43\%, H 8.79\%, N 4.47\%).

$N, N, N$-tris-(phthalimidopropyl)-N-alkylammonium iodides (F18-F19) To $0.025 \mathrm{~mol}$ (14.48 g) molten $N, N, N$-tris-(phthalimidopropyl)amine (B12) was added 0.035 mole of the appropriate alkyl iodide $\left[\mathrm{C}_{3} \mathrm{H}_{7} \mathrm{I}(5.95 \mathrm{~g}), \mathrm{C}_{12} \mathrm{H}_{25} \mathrm{I}(10.37\right.$ g)]. The mixture was heated at $60^{\circ} \mathrm{C}$, respectively for 100 or 180 hours depending on the length of the alkyl chain of the substrate used, preventing the reaction mixture from moisture. Collected $N, N, N$-tris-(phthalimidopropyl)- $N$-alkylammonium iodides (F18-F19) was crystallized from absolute ethanol: F18: R = $\mathrm{C}_{11} \mathrm{H}_{10} \mathrm{NO}_{2^{-}}, \mathrm{R}^{\prime \prime}=\mathrm{C}_{3} \mathrm{H}_{7^{-}}$, yield $66 \%$; m.p. $111^{\circ} \mathrm{C}-113^{\circ} \mathrm{C}$, elemental analysis: $\mathrm{C}$ 57.64\%, H 5.11\%, N 7.53\% (calcd. C 57.76\%, H 4.98\%, N 7.48\%); F19: R = $\mathrm{C}_{18} \mathrm{H}_{37^{-}}, \mathrm{R}^{\prime \prime}=\mathrm{C}_{3} \mathrm{H}_{7^{-}}$, yield $45 \%$; m.p. $75^{\circ} \mathrm{C}-78^{\circ} \mathrm{C}$, elemental analysis: $\mathrm{C} 61.63 \%$, H 6.51\%, N 6.44\% (calcd. C 61.78\%, H 6.34\%, N 6.40\%).

$N, N$-bis-(3-aminopropyl)- $N, N$-dialkylammonium iodides (G1-G17) Corresponding to 0.025 moles of $N, N$-bis-(phthalimidopropyl)- $N, N$-dialkylammonium iodides (F1-F17) dissolved in $50 \mathrm{~mL}$ of anhydrous ethanol was added 0.1 mol (5.01 g) and hydrazine monohydrate was stirred at $20^{\circ} \mathrm{C}$ for $24-60$ hours, depending on the alkyl chain length substrates used. The white, gelatinous precipitate was filtered off and the filtrate was added to $30 \mathrm{~mL}$ of $2 \mathrm{M} \mathrm{HCl}$ to remove all of the phthalic hydrazide derivatives solution. After filtration of the precipitate, the solution was basified by means of $2 \mathrm{M} \mathrm{NaOH}$, and then extracted with methylene chloride $(2 \times 100 \mathrm{~mL})$. The collected organic layer was dried with anhydrous potassium carbonate. After filtering off the drying agent, the solution was evaporated to dryness. The resulting solid was recrystallized from anhydrous ethanol: $\mathrm{G} 1$ : $\mathrm{R}=\mathrm{C}_{3} \mathrm{H}_{7^{-}}, \mathrm{R}^{\prime \prime}=\mathrm{C}_{2} \mathrm{H}_{5^{-}}$, yield $83 \%$; m.p. $172^{\circ} \mathrm{C}-173^{\circ} \mathrm{C}$, 
elemental analysis: C 40.29\%, H 8.62\%, N $12.66 \%$ (calcd. C40.13\%, H 8.57\%, N 12.76\%); G2: $\mathrm{R}=\mathrm{C}_{3} \mathrm{H}_{7^{-}}, \mathrm{R}^{\prime \prime}=\mathrm{C}_{3} \mathrm{H}_{7^{-}}$, yield $80 \%$; m.p. $162^{\circ} \mathrm{C}-163^{\circ} \mathrm{C}$, elemental analysis: C 41.75\%, H 8.99\%, N 12.13\% (calcd. C 41.98\%, H 8.81\%, N 12.24\%); G3: $\mathrm{R}=\mathrm{C}_{3} \mathrm{H}_{7^{-}}, \mathrm{R}^{\prime \prime}=\mathrm{C}_{4} \mathrm{H}_{9^{-}}$, yield $47 \%$; m.p. $142^{\circ} \mathrm{C}-144^{\circ} \mathrm{C}$, elemental analysis: $\mathrm{C}$ 43.55\%, H 8.95\%, N 11.70\% (calcd. C 43.70\%, H 9.03\%, N 11.76\%); G4: R = $\mathrm{C}_{3} \mathrm{H}_{7^{-}}, \mathrm{R}^{\prime \prime}=\mathrm{C}_{6} \mathrm{H}_{13^{-}}$, yield $77 \%$; m.p. $115^{\circ} \mathrm{C}-117^{\circ} \mathrm{C}$, elemental analysis: $\mathrm{C} 46.98 \%$, $\mathrm{H} 9.66 \%$, N 10.72\% (calcd. C 46.75\%, H 9.42\%, N 10.90\%); G5: R = $\mathrm{C}_{3} \mathrm{H}_{7^{-}}, \mathrm{R}^{\prime \prime}=$ $\mathrm{C}_{8} \mathrm{H}_{17^{-}}$, yield $62 \%$; m.p. $99^{\circ} \mathrm{C}-101^{\circ} \mathrm{C}$, elemental analysis: $\mathrm{C} 49.71 \%, \mathrm{H} 9.88 \%, \mathrm{~N}$ $10.05 \%$ (calcd. C 49.39\%, H 9.75\%, N 10.16\%); G6: $\mathrm{R}=\mathrm{C}_{3} \mathrm{H}_{7^{-}}, \mathrm{R}^{\prime \prime}=\mathrm{C}_{10} \mathrm{H}_{21^{-}}$, yield $65 \%$; m.p. $82^{\circ} \mathrm{C}-84^{\circ} \mathrm{C}$, elemental analysis: C 51.52\%, H 10.22\%, N 9.44\% (calcd. C 51.69\%, H 10.05\%, N 9.52\%); G7: $\mathrm{R}=\mathrm{C}_{3} \mathrm{H}_{7^{-}}, \mathrm{R}^{\prime \prime}=\mathrm{C}_{12} \mathrm{H}_{25^{-}}$, yield 61\%; m.p. $75^{\circ} \mathrm{C}-77^{\circ} \mathrm{C}$, elemental analysis: C 53.88\%, H 10.41\%, N 8.86\% (calcd. C $53.72 \%, \mathrm{H} 10.30 \%$, N 8.95\%); G8: $\mathrm{R}=\mathrm{C}_{3} \mathrm{H}_{7^{-}}, \mathrm{R}^{\prime \prime}=\mathrm{C}_{16} \mathrm{H}_{33^{-}}$, yield 57\%; m.p. $66^{\circ} \mathrm{C}$ - $68^{\circ} \mathrm{C}$, elemental analysis: C 57.01\%, H 10.91\%, N 7.805.41\% (calcd. C 57.12\%, $\mathrm{H} 10.74 \%$, N 7.99\%); G9: $\mathrm{R}=\mathrm{C}_{3} \mathrm{H}_{7^{-}}, \mathrm{R}^{\prime \prime}=\mathrm{C}_{18} \mathrm{H}_{37^{-}}$, yield $54 \%$; m.p. $50^{\circ} \mathrm{C}-52^{\circ} \mathrm{C}$, elemental analysis: C 58.33\%, H 11.09\%, N 7.30\% (calcd. C 58.57\%, H 10.92\%, N 7.59\%); G10: $\mathrm{R}=\mathrm{C}_{4} \mathrm{H}_{9}-, \mathrm{R}^{\prime \prime}=\mathrm{C}_{4} \mathrm{H}_{9}-$, yield $72 \%$; m.p. $158^{\circ} \mathrm{C}-160^{\circ} \mathrm{C}$, elemental analysis: C 45.59\%, H 9.47\%, N 11.09\% (calcd. C 45.28\%, H 9.23\%, N 11.32\%); G11: $\mathrm{R}=\mathrm{C}_{6} \mathrm{H}_{13^{-}}, \mathrm{R}^{\prime \prime}=\mathrm{C}_{6} \mathrm{H}_{13^{-}}$, yield $75 \%$; m.p. $109^{\circ} \mathrm{C}-110^{\circ} \mathrm{C}$, elemental analysis: C 50.70\%, H 9.97\%, N 9.69\% (calcd. C 50.58\%, H 9.90\%, N 9.83\%); G12: R = $\mathrm{C}_{8} \mathrm{H}_{17^{-}}, \mathrm{R}^{\prime \prime}=\mathrm{C}_{8} \mathrm{H}_{17^{-}}$, yield $68 \%$; m.p. $55^{\circ} \mathrm{C}-56^{\circ} \mathrm{C}$, elemental analysis: $\mathrm{C} 54.75 \%$, H 10.53\%, N 8.60\% (calcd. C 54.64\%, H 10.42\%, N 8.69\%); G13: R = $\mathrm{C}_{10} \mathrm{H}_{21^{-}}, \mathrm{R}^{\prime}$ $=\mathrm{C}_{10} \mathrm{H}_{21^{-}}$, yield $61 \%$; m.p. $67^{\circ} \mathrm{C}-69^{\circ} \mathrm{C}$, elemental analysis: $\mathrm{C} 57.91 \%, \mathrm{H} 10.91 \%$, N 7.68\% (calcd. C 57.87\%, H 10.83\%, N 7.79\%); G14: R = $\mathrm{C}_{12} \mathrm{H}_{25}{ }^{-}, \mathrm{R}^{\prime \prime}=\mathrm{C}_{12} \mathrm{H}_{25^{-}}$, yield $61 \%$; m.p. $50^{\circ} \mathrm{C}-52^{\circ} \mathrm{C}$, elemental analysis: C $60.61 \%, \mathrm{H} 11.38 \%, \mathrm{~N} 7.11 \%$ (calcd. C 60.48\%, H 11.17\%, N 7.05\%); G15: $\mathrm{R}=\mathrm{C}_{18} \mathrm{H}_{37^{-}}, \mathrm{R}^{\prime \prime}=\mathrm{C}_{18} \mathrm{H}_{37^{-}}$, yield $53 \%$; m.p. $55^{\circ} \mathrm{C}-57^{\circ} \mathrm{C}$, elemental analysis: C 66.15\%, H $11.99 \%$, N 5.39\% (calcd. C 66.02\%, H 11.87\%, N 5.50\%); G16: $\mathrm{R}=\mathrm{C}_{8} \mathrm{H}_{17^{-}}, \mathrm{R}^{\prime \prime}=\mathrm{C}_{12} \mathrm{H}_{25^{-}}$, yield 67\%; m.p. $63^{\circ} \mathrm{C}-65^{\circ} \mathrm{C}$, elemental analysis: C 57.94\%, H 10.71\%, N 7.72\% (calcd. C 57.87\%, $\mathrm{H} 10.83 \%, \mathrm{~N} 7.79 \%$ ); G17: $\mathrm{R}=\mathrm{C}_{12} \mathrm{H}_{25^{-}}, \mathrm{R}^{\prime \prime}=\mathrm{C}_{18} \mathrm{H}_{37^{-}}$, yield 52\%; m.p. $56^{\circ} \mathrm{C}-$ $57^{\circ} \mathrm{C}$, elemental analysis: C 63.67\%, H 11.62\%, N 6.11\% (calcd. C 63.59\%, H $11.56 \%, \mathrm{~N} 6.18 \%)$.

\subsection{Antimicrobial Assay}

Antimicrobial activity of the synthesized compounds was evaluated against two species of bacteria: Escherichia coli ATCC 10536 and Staphylococcus aureus ATCC 6538, and two species of fungi: Candida albicans ATCC 10231, and Aspergillus niger ATCC 16401. Minimal inhibitory concentrations (MIC) were measured by a tube standard 2-fold dilution method, i.e. the volume of the original solution is always doubled, as in going from 1 to 2 . Bacteria were preincubated on Tripticase Soy Broth (TSB) slant for 1 day at $37^{\circ} \mathrm{C}$ and fungi were preincubated on Malt Extract Broth (MEB); A.niger for 5 days at $28^{\circ} \mathrm{C}, \mathrm{C}$. albicans for 1 day at $37^{\circ} \mathrm{C}$. Conidia suspensions were prepared by adding sterile water containing $0.1 \%(\mathrm{w} / \mathrm{w})$ Tween 80 to the slant. The bacteria and yeasts cell 
suspension were prepared by similar procedure but without Tween 80 . One $\mathrm{mL}$ of inoculum (density $10^{6}$ cells $\mathrm{mL}^{-1}$ ) was mixed with $1 \mathrm{~mL}$ of media containing the tested compounds and incubated for $24 \mathrm{~h}$ at $30^{\circ} \mathrm{C}$ for fungi, and $37^{\circ} \mathrm{C}$ for bacteria. The MIC's were defined as the lowest concentrations of the compounds at which there was no visible growth.

\section{Results and Discussion}

\subsection{Chemistry}

The synthetic routes providing to norspermidine derivatives (A-G) are presented on Scheme 1. The reactions were carried out in polar, protic solvents. The reaction time depends on the length of the alkyl chain; the longer chain the longer reaction time. To get the highest yields reaction time and temperature were optimized. The synthetic procedures to obtain new norspermidine derivatives are similar to some extent to those given in the literaure [25]. A variety of polyamines have also been synthesized from their corresponding amino alcohols through a 3-step process. The synthesis predicates that the most likely impurities are of higher molecular weight and that distillation is effective at producing highly pure materials. This sequence is scalable, requires no protecting groups or chromatography, and provides the requisite polyamines in moderate to good yields [26].

$N, N$-bis-(phthalimidopropyl)amine (A) was prepared by refluxing commercially available $N, N$-bis-(-3-aminopropyl)amine and phthalic anhydride in acetic acid [22] [23]. Reaction of equimolar amounts of $N, N$-bis-(phthalimidopropyl) amine (A) and suitable bromoalkane under reflux in ethanol for 18 - 36 hours gave corresponding $N, N$-bis-(phthalimidopropyl)- $N$-alkylamines (B). Hydrochlorides of $N, N$-bis-(phthalimidopropyl)amine (C) and $N, N$-bis-(phthalimidopropyl)- $N$-alkylamines (D) were obtained by reaction with hydrochloride acid in

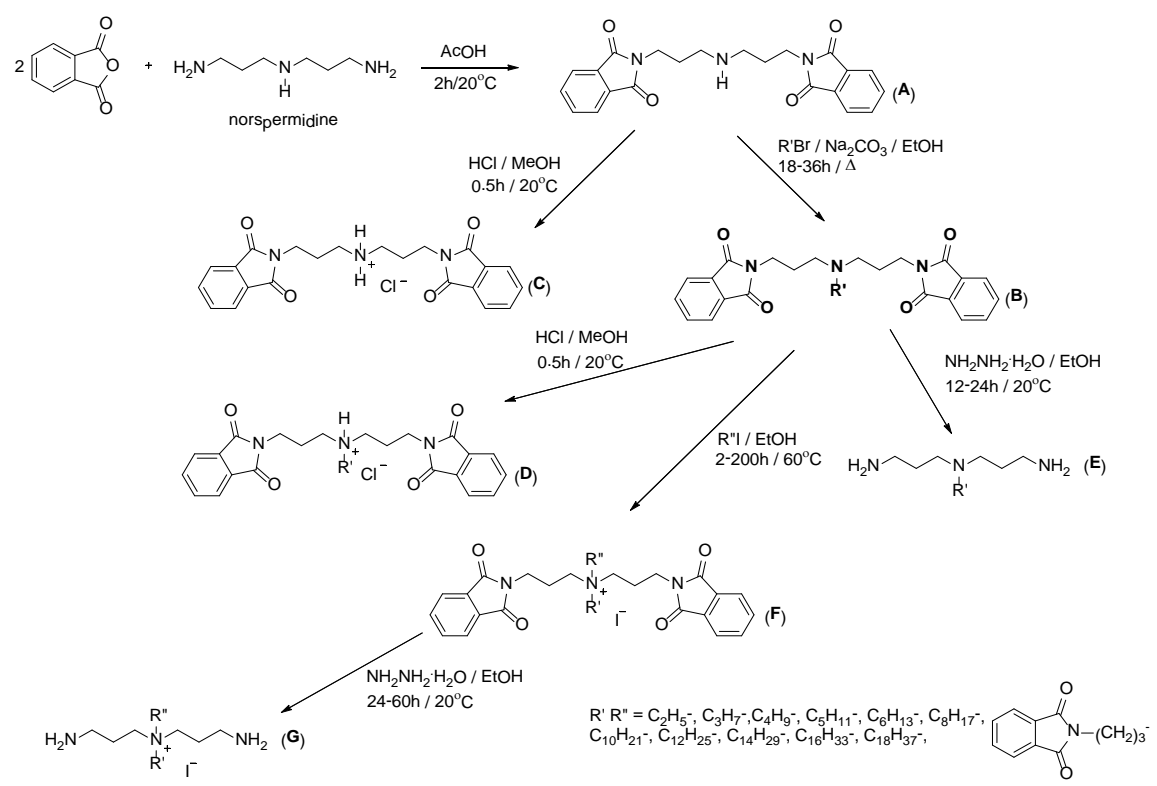

Scheme 1. Synthesis of norspermidine derivatives. 
methanol. To prepare $N, N$-bis-(phthalimidopropyl)- $N, N$-dialkylammonium iodides (F) the reactions of $N, N$-bis-(phthalimidopropyl)- $N$-alkylamines (B) with an appropriate alkyl iodides were exploited using two methods. In Method I methanol as a solvent was used whereas no solvent was used in Method II. Yields of reactions were high, regardless of the synthetic method. However, the reaction time strongly depends on the length of alkyl iodide used. The longer hydrocarbon chain the longer reaction time. $N, N$-bis-(3-aminopropyl)- $N$-alkylamines (E) and $N, \mathrm{~N}$-bis-(3-aminopropyl)- $N, N$-dialkylammonium iodides (G) were obtained in reactions of corresponding $N, N$-bis-(phthalimidopropyl)- $N$ alkylamines (B) and $N, N$-bis-(phthalimidopropyl)- $N, N$-dialkylammonium iodides (F) with hydrazine monohydrate at $20^{\circ} \mathrm{C}$ for $24-60$ hours depending on the alkyl chain length.

Three representative molecular models of $N, N$-bis-(3-aminopropyl)- $N$-dodecylamine (E4), $N, N$-bis-(3-aminopropyl)- $N, N$-didodecylammonium iodide (G14) and $N, N$-bis-(phthalimidopropyl)- $N, N$-didodecylammonium iodide(F14) were performed by PM5 semiempirical calculations using the WinMopac 2003 program (Chart 1). The final heat of formation (HOF), distances of $\mathrm{N}^{-\mathrm{CH}_{2}}$ and $\mathrm{N} \cdots \mathrm{Br}$, bond angle of $\mathrm{N}-\mathrm{CH}_{2}-\mathrm{CH}_{2}$ as well as dihedral angle of $\mathrm{N}-\mathrm{CH}_{2}-\mathrm{CH}_{2}-\mathrm{CH}_{2}-$ $\mathrm{CH}_{2}$ are presented in Table 1. The lowest HOF value is observed for F14, wherein all amino groups are blocked. The geometry of $N, N$-bis-(phthalimidopropyl)- $N, N$-didodecylammonium iodide (F14) and $N, N$-bis-(3-aminopropyl)$N, N$-didodecylammonium iodides (G14) are not substantially changed. The long alkyl chains are located perpendicular to the chains containing nitrogen atoms.

All phthalimide derivatives of norspermidine (A,B,C,D,F) as well as dialkyl derivatives (G) are solids. Melting points of these compounds strongly depend on the alkyl chain length. The longer alkyl chain the lower melting point. This is due to the higher degree of freedom of longer alkyl chains what reduces the

(a)

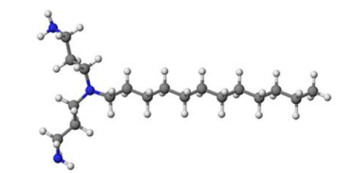

(b)

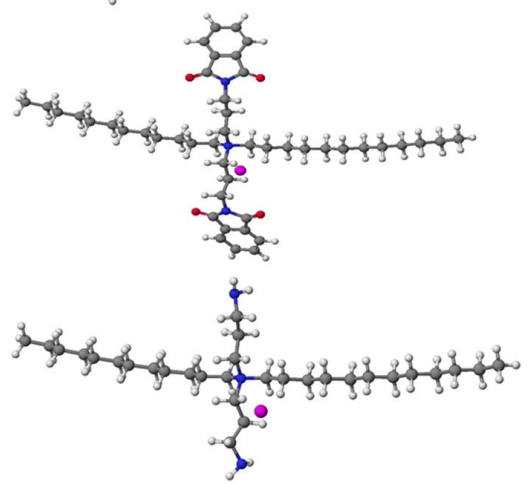

Chart 1. Molecular models of $N, N$-bis-(3-aminopropyl)- $N$-dodecylamine (E4) (a), $N, N$-bis-(phthalimidopropyl)- $N, N$-didodecylammonium iodide (F14) (b) and $N, N$-bis(3-aminopropyl)- $N, N$-didodecylammonium iodides (G14) (c). 
Table 1. Heat of formation (HOF) [ $\mathrm{kcal} / \mathrm{mol}]$, distances of $\mathrm{N}-\mathrm{CH}_{2}$ and $\mathrm{N} \cdots \mathrm{Br}[\AA]$, bond angle of $\mathrm{N}-\mathrm{CH}_{2}-\mathrm{CH}_{2}$ and dihedral angle of $\mathrm{N}-\mathrm{CH}_{2}-\mathrm{CH}_{2}-\mathrm{CH}_{2}-\mathrm{CH}_{2}\left[^{\circ}\right.$ ] of compounds (E4), (F14) and (G14).

\begin{tabular}{|c|c|c|c|c|c|}
\hline Compounds & $\begin{array}{c}\text { HOF } \\
{[\mathrm{kcal} / \mathrm{mol}]}\end{array}$ & $\begin{array}{l}\text { Distance }[\AA] \\
\text { of } \mathrm{N}-\mathrm{CH}_{2}\end{array}$ & $\begin{array}{c}\text { Distance }[\AA] \\
\text { of } \mathrm{N} \cdots \mathrm{Br}\end{array}$ & $\begin{array}{c}\text { Bond Angle }\left[{ }^{\circ}\right] \text { of } \\
\text { N-CH }-\mathrm{CH}_{2}-\mathrm{CH}_{2}\end{array}$ & $\begin{array}{l}\text { Dihedral angle }\left[{ }^{\circ}\right] \text { of } \\
\mathrm{N}-\mathrm{CH}_{2}-\mathrm{CH}_{2}-\mathrm{CH}_{2}-\mathrm{CH}_{2}\end{array}$ \\
\hline \multirow{3}{*}{ E4 } & \multirow{3}{*}{-72.9500} & \multirow{3}{*}{1.491} & \multirow{3}{*}{-} & 109.692 & -176.477 \\
\hline & & & & 109.655 & -175.288 \\
\hline & & & & 109.808 & -174.425 \\
\hline \multirow{4}{*}{ F14 } & \multirow{4}{*}{-199.0620} & \multirow{4}{*}{1.536} & \multirow{4}{*}{3.980} & 114.606 & -174.870 \\
\hline & & & & 113.845 & -174.879 \\
\hline & & & & 114.640 & 173.874 \\
\hline & & & & 113.691 & 178.628 \\
\hline \multirow{4}{*}{ G14 } & \multirow{4}{*}{-111.6305} & \multirow{4}{*}{1.536} & \multirow{4}{*}{3.986} & 114.283 & -168.997 \\
\hline & & & & 114.033 & -158.903 \\
\hline & & & & 114.733 & 176.179 \\
\hline & & & & 114.034 & 176.925 \\
\hline
\end{tabular}

crystallinity of the compounds. For example the melting points spam between ethyl and octadecyl derivatives of $N, N$-bis-(phthtalimidopropyl)- $N$-alkylamines (B) is over $70^{\circ} \mathrm{C}$. $N, N$-bis(3-aminopropyl)- $N$-alkylamines (E) are oils with high boiling points which raises as the length of the alkyl substituent increases.

The most characteristic feature in the FTIR spectra of phthalimide derivatives of norspermidine (A,B,C,D and F) in the solid state are carbonyl bands in the region of $1698-1774 \mathrm{~cm}^{-1}$ (Tables S1-S4 in the Supplementary material) (Chart 2). In all cases, i.e. for $N, N$-bis-(phthalimidopropyl)amine (A), $N, N$-bis-(phthalimi-dopropyl)- $N$-alkyl-amines (B1-B11), $N, N, N$-tris-(phthalimidopropyl) amine (B12), $N, N$-bis-(phthalimidopropyl)ammonium hydrochloride (C), $N, N$-bis (phthalimidopropyl)- $\mathrm{N}$-alkylammonium hydrochlorides (D1-D11), $\mathrm{N}, \mathrm{N}, \mathrm{N}$-tris(phthalimidopropyl)ammonium hydrochloride (D12), N,N-bis-(phthalimidopropyl)- $N, N$-dialkylammonium iodides (F1-F17) and $N, N, N$-tris(phthalimidopropyl)- $N$-alkylammonium iodides (F18-F19) asymmetric stretching vibrations of the carbonyl group in the region of $1764-1774 \mathrm{~cm}^{-1}$ and a broad and intense band of symmetric stretching vibrations in the region of $1698-1718 \mathrm{~cm}^{-1}$ are observed (Tables S1-S4 in the Supplementary material (Chart 2).

The intensity of asymmetric stretching vibrations of the carbonyl group in the observed spectra is significantly lower in comparison to the intensity of symmetric stretching vibrations. It is usually due to the symmetry of molecule. Moreover, in the most cases of $N, N$-bis-(phthalimidopropyl)- $N$-alkylamines (B) both asymmetric and symmetric stretching vibration bands are split what indicates the nonequivalence of carbonyl groups in the phthalimide moiety (Table S1 in the Supplementary material). $N, N$-bis-(phthalimidopropyl)- $N$-octadecylamine (B11) is a typical example where the asymmetric carbonyl band vas $(\mathrm{C}=\mathrm{O})$ lie at 1773 and $1767 \mathrm{~cm}^{-1}$ whereas the symmetric carbonyl band is $(\mathrm{C}=\mathrm{O})$ lie at 1724 and $1707 \mathrm{~cm}^{-1}$. For two $N, N$-bis-(phthalimidopropyl)- $N$-alkylamines, i.e. $N, N$ bis-(phthalimidopropyl)- $N$-propylamine (B2) and $N, N$-bis-(phthalimidopropyl)- $N$-octylamine (B6) the crystal structures have been previously determined [22] [23]. The small differences of the lengths and angles of carbonyl groups in the phthalimide moiety were observed which are reflected in splitting 


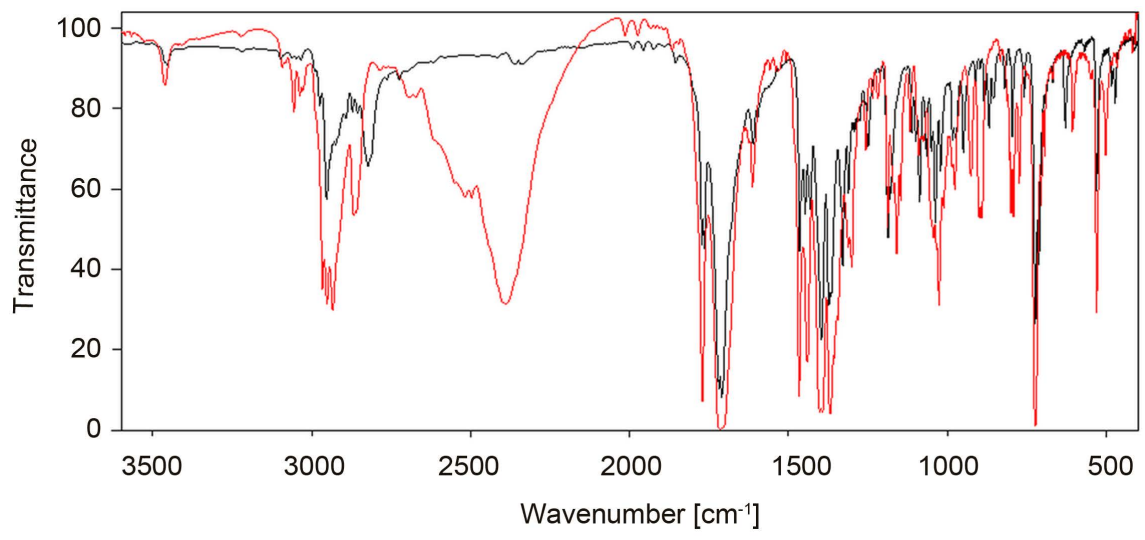

Chart 2. FTIR spectra of $N, N$-bis-(phthalimidopropylamino)- $N$-hexylamine (B5) (black) and $N, N$-bis-(phthalimidopropylamino)- $N$-hexylammonium hydrochloride (D5) (red).

of carbonyl bands in FTIR spectra. The asymmetric and symmetric stretrching vibrations of carbonyl groups are also observed in Raman spectra. However, the intensities of these bands are reversed in a comparison to FTIR spectra. The intensities of asymmetric vibrations of carbonyl bands are very strong, whereas the intensity of symmetric vibrations are weak [22] [23]. In general the positions and intensity of carbonyl group bands in each series of phthalimide derivatives of norspermidine are very similar. It means that spacer substituents have neglegible effect on carbonyl group of phthalimide ring. However, some effects are observed between series of $N, N$-bis-(phthalimidopropyl)- $N$-alkylamines (B1B11), $N, N$-bis-(phthalimidopropyl)- $N$-alkylammonium hydrochlorides (D1D11) and $N, N$-bis-(phthalimidopropyl)- $N, N$-dialkylammonium iodides (F1F17). Protonation or quaternization of $N, N$-bis-(phthalimidopropyl)- $N$-alkylamines (B1-11) introduce a positive charge to molecule what causes a slightly shift of symmetric vibrations of carbonyl band to lower frequencies in series D and $\mathrm{F}$.

Protonation of $N, N$-bis-(phthtalimidopropyl)amine (A) brings two broad and intense bands of $\mathrm{NH}$ groups. One of the bands of $\mathrm{NH}$ groups appears at 3650 $3260 \mathrm{~cm}^{-1}$ with a maximum absorption at $3463 \mathrm{~cm}^{-1}$. The second band is present in the region of $2870-2595 \mathrm{~cm}^{-1}$ with a maximum absorption at $2789 \mathrm{~cm}^{-1}$ and corresponds to the $\mathrm{N}-\mathrm{H} \cdots \mathrm{Cl}$ hydrogen bond. For hydrochlorides of $\mathrm{N}, \mathrm{N}$-bis(phthtalimidopropyl)- $N$-alkylamines (D) the broad and intense bands of the $\mathrm{NH} \cdots \mathrm{Cl}$ are observed in the region of $2459-2338 \mathrm{~cm}^{-1}$ (Table S2 in the Supplementary material). The maximum of this band shifts toward lower frequencies with an increasing length of alkyl chain, from $2420 \mathrm{~cm}^{-1}$ for $N, N$-bis-(phthtalimidopropyl)- $N$-ethylamine (B2) to $2344 \mathrm{~cm}^{-1}$ for $N, N$-bis-(phthtalimidopropyl)- $N$-octadecylamine (B11). This effect is due to lengthening of hydrogen bond caused by an increase of electrodonor properties of longer alkyl substituents.

The most characteristic feature in FTIR spectra of $N$-alkyl derivatives of norspermidine, both neutral (series E) and cationic (series G), are asymmetric and 
symmetric vibration bands of $\mathrm{NH}_{2}$ group. The asymmetric vibrations $v_{\text {as }}(\mathrm{N}-\mathrm{H})$ appear around $3363 \mathrm{~cm}^{-1}$ for $N, N$-bis-(3-aminopropyl)- $N$-alkylamines (E1-E6) as well as $N, N$-bis-(3-aminopropyl)- $N, N$-dialkiloammonium iodides (G1-G17) (Table S3 in the Supplementary material). The symmetric vibrations $v_{\mathrm{s}}(\mathrm{N}-\mathrm{H})$ for these two series lie around $3285 \mathrm{~cm}^{-1}$. It means that trimethylene spacers efficiently block electronic effect of positively charged nitrogen atom on terminal amine groups.

The proton chemical shift assignments (Tables S5-S9 in the Supplementary material) are based on the 2D COSY experiments, in which the proton-proton connectivity is observed through the off-diagonal peaks in the contour plot.

The use of 2D NMR techniques is of great importance to determine the position of the hydrogen atoms in the molecule. These methods are extensively described in literature [27] [28] [29].This allows to establish the $\mathrm{H}-\mathrm{H}$ connectivity in the molecule and helps to remove ambiguities in the assignment of the complex proton resonance. The $2 \mathrm{D}$ heteronuclear shifts correlated counter map (HETCOR) has been used to identify resonance in the ${ }^{13} \mathrm{C}$ NMR spectra (Chart 3) $[24][30]$.

In the ${ }^{1} \mathrm{H}$ NMR spectra of $N, N$-bis-(phthalimidopropyl)- $N$-alkylamines (B1B12) multipletsin the region of $\delta=7.70-7.83$ ppm were observed which belong to protons of aryl groups (Table S5 in the Supplementary material). Protons of trimethylene spacer exhibit two triplets in the region $\delta=2.48\left(\mathrm{CH}_{2}-\mathrm{N}\right)$ and $\delta=$ $3.73 \mathrm{ppm}\left(\mathrm{CH}_{2}-\mathrm{NPh}\right)$ and one multiplet $\left(\mathrm{C}-\mathrm{CH}_{2}-\mathrm{C}\right)$ in the region of $\delta=1.80 \mathrm{ppm}$ (Table S5 in the Supplementary material). Protons of terminal methyl group of the alkyl substituent are observed as triplet at $0.88 \mathrm{ppm}$ whereas protons of

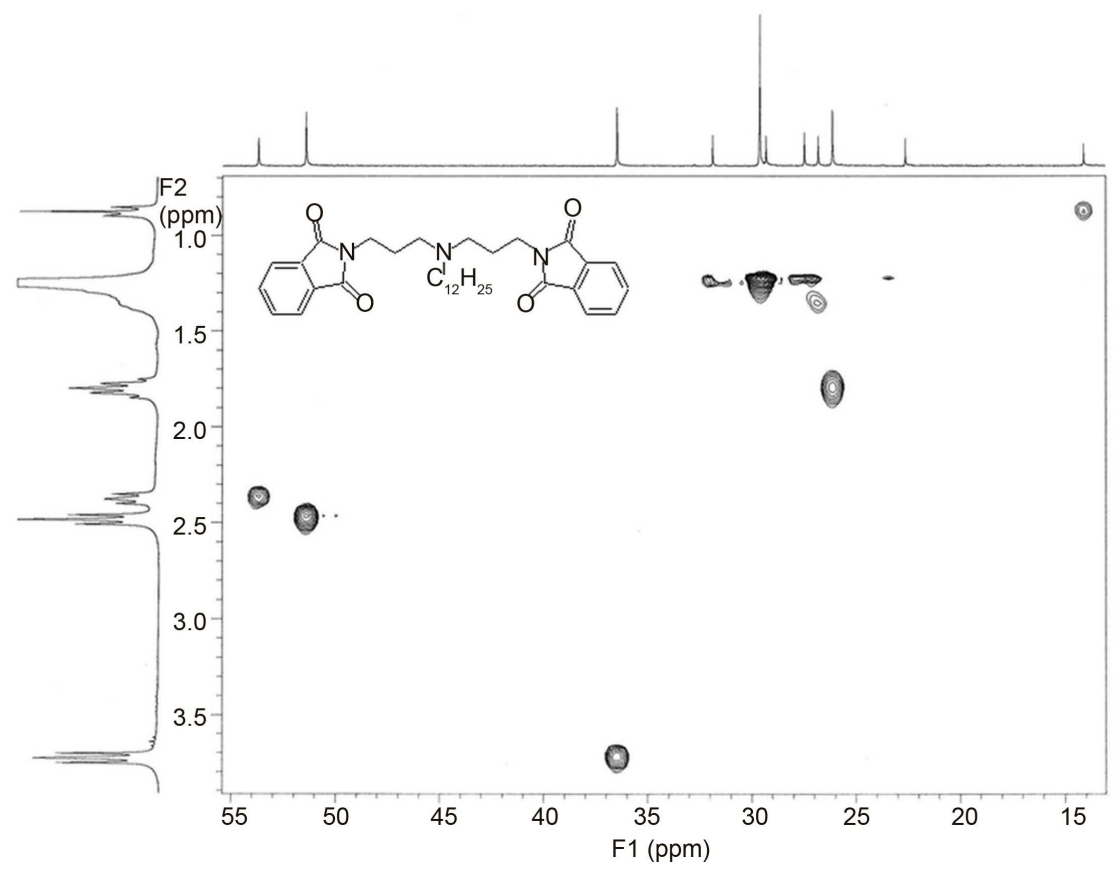

Chart 3. ${ }^{1} \mathrm{H},{ }^{13} \mathrm{C}$ HETCOR spectrum of $N, N$-bis-(phthalimidopropylamino)- $N$-dodecylamine (B8). 
methylene group attached to tertiary nitrogen atom $\left(\mathrm{CH}_{2}-\mathrm{N}\right)$ exhibit a triplet at $2.38 \mathrm{ppm}$. A complex signal of methylene groups of alkyl substituent lie between $1.25-1.40 \mathrm{ppm}$. The change of the length of the alkyl chain practically does not influence the chemical shifts of methylene spacer protons.

The proton chemical shifts of hydrochlorides of $N, N$-bis-(phthalimidopropyl)- $N$-alkylamines (D1-D12) are given in Table S6 in the Supplementary material. Protons of methylene groups in the spacer which are attached to nitrogen atoms are deshielded and shifted to higher values of ppm, while the protons of the central methylene group are slightly shifted toward lower values of ppm in comparison to chemical shifts of protons of the corresponding free bases (B). The similar effects are observed for chemical shifts of spacer protons of $N, N$-bis(phthalimidopropyl)- $N, N$-dialkylammonium iodides (F) (Table S8 in the Supplementary material). The assignment of the individual signals corresponding protons was made possible through the use of correlation spectroscopy, 2D COSY and HETCOR NMR (Chart 4 and Chart 5). However in the case of $N, N$ bis-(phthalimidopropyl)- $N, N$-dialkylammonium iodides (F) all protons are stronger deshielded and shifted to higher values of ppm in comparison to corresponding hydrochlorides. This is due to the fact that in quaternized amines there are no free electrons on nitrogen atom, while for hydrochlorides there is only hydrogen bonded ion pair where nitrogen atom is protonated to some extent depending on the conditions.

Aromatic protons of phthalimide moiety of $N, N$-bis-(phthalimidoprop-yl)$N$-alkylamines (B), hydrochlorides of $N, N$-bis-(phthalimidopropyl)- $N$-alkylamines (D) and $N, N$-bis-(phthalimidopropyl)- $N, N$-dialkylammonium iodides (F) give a multiplet of AA'XX' type in ' ${ }^{1} \mathrm{H}$ NMR (Chart 6).

The shape and chemical shift of this multiplet strongly depends on temperature. Barret et al. [31] and Howell et al. [32] showed that this multiplet can coalesce with a rising temperature giving even a singlet, and then go again to dublet

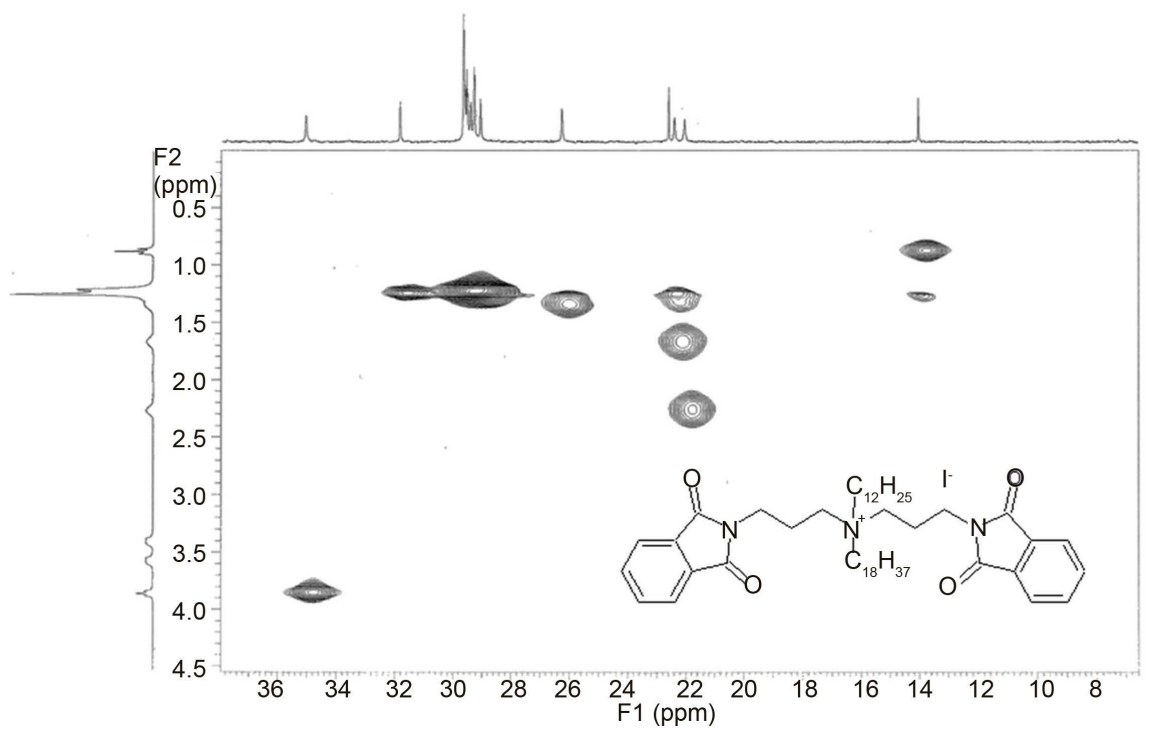

Chart 4. HETCOR 2D NMR spectrum of $N, N$-bis-(phthalimidopropyl)- $N$-dodecyl$\mathrm{N}$-octadecylammonium iodide (F17) (aliphatic range). 


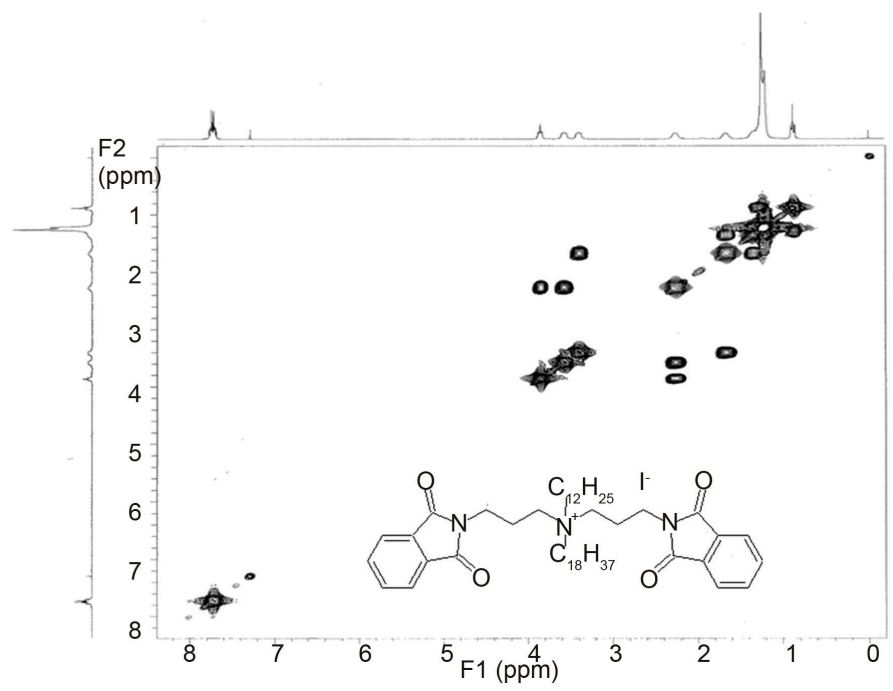

Chart 5. 2D COSY NMR spectrum of $N, N$-bis-(phthalimidopropyl)- $N$-dodecyl- $N$-octadecylammonium iodide (F17).
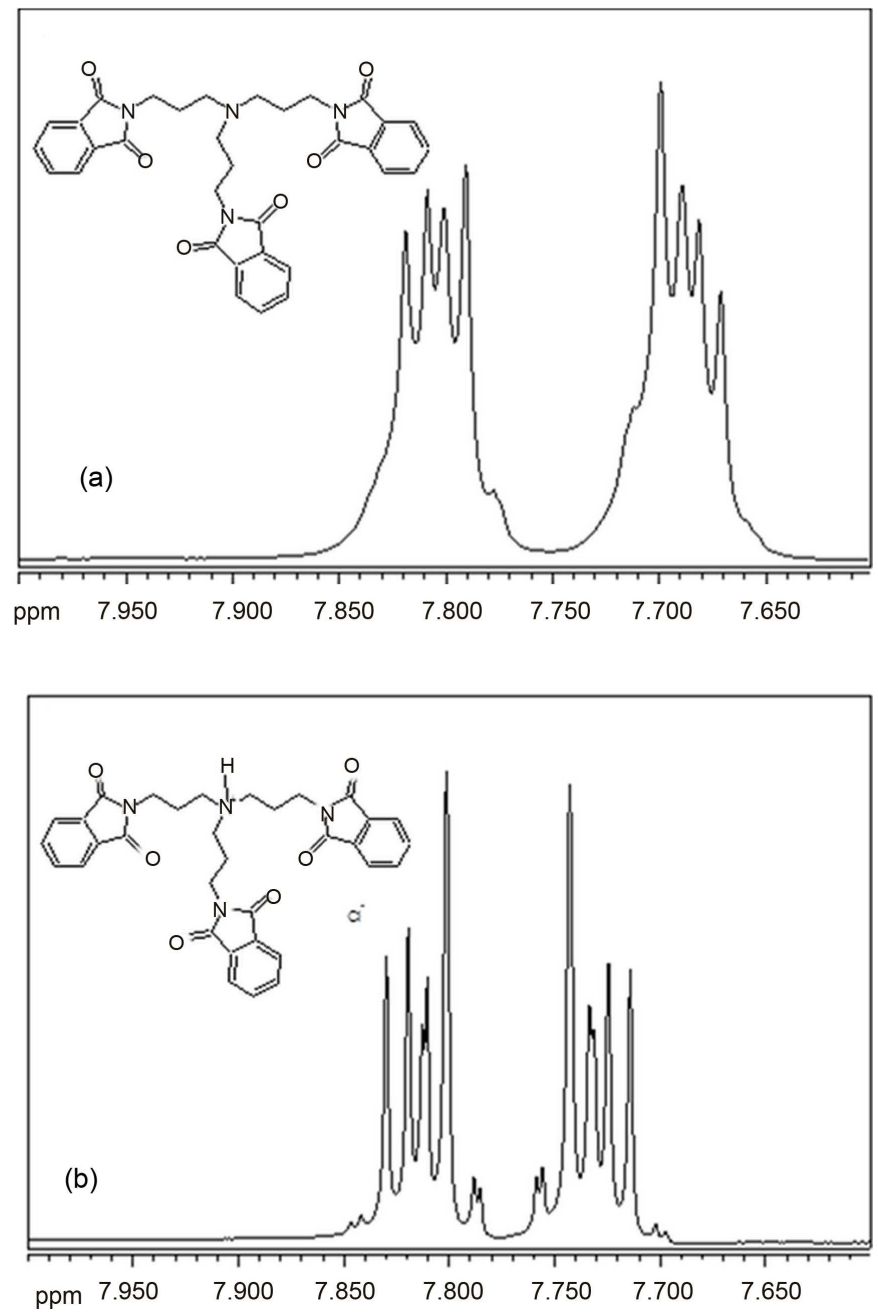

Chart 6. ${ }^{1} \mathrm{H}$ NMR $\left(\mathrm{CDCl}_{3}\right)$ spectra in the aromatic range for (a) $N, N, N$-tris (phthalimidopropyl) amine (B12) and (b) $N, N, N$-tris-(phthalimidopropyl)-ammonium hydrochloride (D12). 
of dublet. Authors explained a such behavior of protons by dynamic interactions of phthalimide ring caused by $n-\pi$ interactions of tertiary nitrogen atom with phthalimide ring as well by $\pi-\pi$ interactions of phthalimide moieties. However our study of analogous naphthalimide derivatives showed that this effect is exclusively caused by changing geometry of carbonyl group caused by a rising temperature and no $n-\pi$ and $\pi-\pi$ interactions take place [33].

The proton chemical shift assignments of $N, N$-bis-(3-aminopropyl)- $N$-alkylamines (E) and $N, N$-bis-(3-aminopropyl)- $N, N$-dialkylammonium iodides (G) are based on the 2D COSY experiments (Chart 7). The ${ }^{1} \mathrm{H}$ NMR chemical shifts are given in Table S7 and Table $\$ 9$ in the Supplementary material. For $N, N$ bis-(3-aminopropyl)- $N$-alkylamines (E) chemical shifts of spacer methylene protons are not affected by the length of alkyl substituent. Protons of methylene group attached to tertiary nitrogen atom $\left(\mathrm{CH}_{2}-\mathrm{N}\right)$ resonate at $2.45 \mathrm{ppm}$ and protons of methylene group attached to primary amine group give signals at 2.72 ppm. Protons of central methylene group resonate at $1.59 \mathrm{ppm}$. Quaternization of tertiary nitrogen atom causes the shifts of protons to higher values around 3.5, 3.11 and 2.20 ppm, respectively.

${ }^{13} \mathrm{C}$ NMR spectra of phthalimide derivatives of norspermidine, i.e. $N, N$-bis(phthalimidopropyl)- $N$-alkylamines (B), hydrochlorides of $N, N$-bis-(phthalimidopropyl)- $N$-alkylamines (D) and $N, N$-bis-(3-aminopropyl)- $N, N$-dialkylammonium iodides $(G)$ exhibit three groups of signals. The first one are peaks of carbons of carbonyl groups at $168.5 \mathrm{ppm}$, the second one are signals of aromatic carbon atoms at around 132, 134 and $123 \mathrm{ppm}$ and the third one are peaks of aliphatic carbon atoms at the range from 11 to 60 ppm (Table S10, Table S11, Table S13 and Table S14 in the Supplementary material).

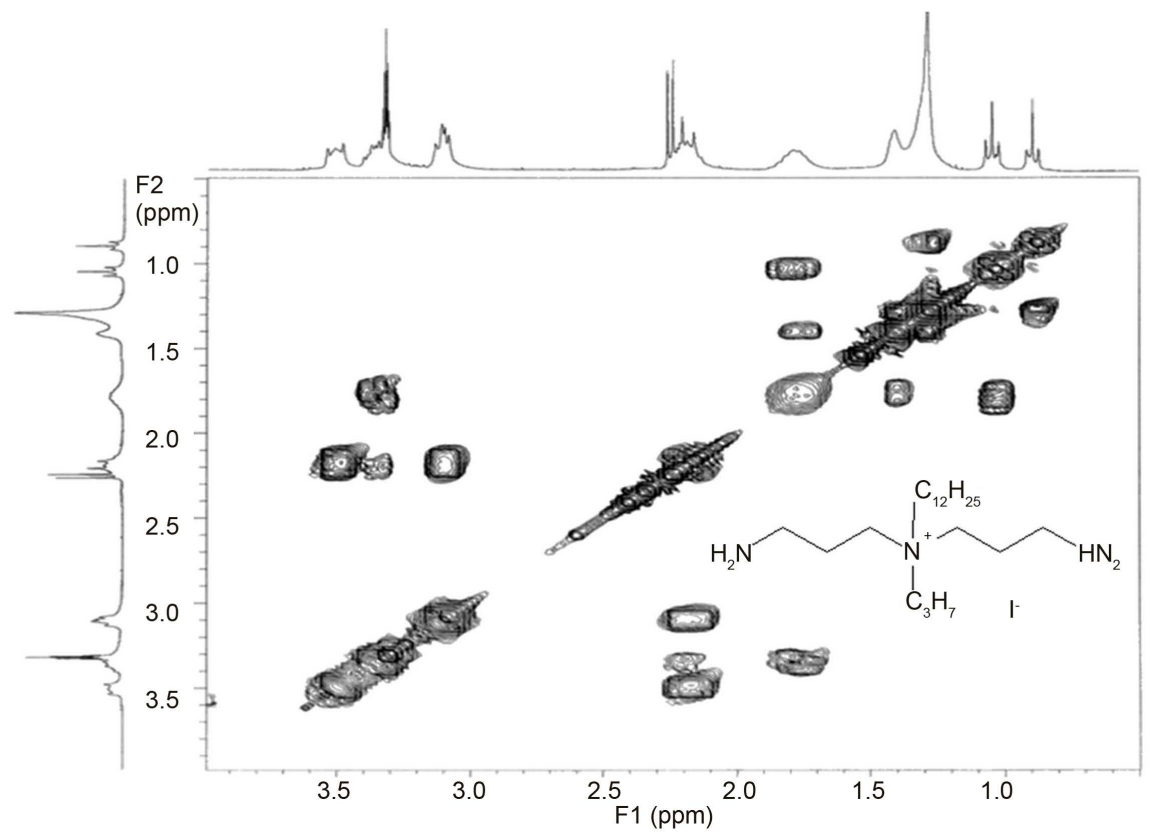

Chart 7. COSY spectrum of $N, N$-bis-(3-aminopropyl)- $N$-dodecyl- $N$-propylammonium iodide (G7). 
The chemical shifts of carbonyl and aromatic carbons are nearly insensitive on protonation or quaternization of tertiary nitrogen atom in molecule. They are also do not reflect the changes of the lengths of alkyl substituent (Table S10, Table S11 and Table S14 in the Supplementary material). ${ }^{13} \mathrm{C}$ NMR spectra of alkyl derivatives of norspermidine, i.e. $N, N$-bis-(3-aminopropyl)- $N$-alkylamines (E) and $N, N$-bis-(3-aminopropyl)- $N, N$-dialkylammonium iodides (G) exhibit only aliphatic carbon atoms peaks in the range from 11 to $62 \mathrm{ppm}$ (Table S12 and Table S14 in the Supplementary material). The most sensitive to electron effects is carbon atom attached to central, tertiary nitrogen atom $\left(\mathrm{CH}_{2}-\mathrm{N}\right)$. The chemical shift of this carbon in $N, N$-bis-(3-aminopropyl)- $N$-alkylamines (E) is $51.8 \pm 0.2 \mathrm{ppm}$. A very similar value of chemical shifts of this carbon is observed for phthalimide derivatives, i.e. $N, N$-bis-(phthalimidopropyl)- $N$-alkylamines (B). The average chemical shift for this atom is $51.4 \pm 0.2 \mathrm{ppm}$.

Quaternization of nitrogen atom introduce a positive charge to molecule. As a result of this the higher values of chemical shifts of carbon atoms attached to positively charged nitrogen atoms are observed. In a series of asymmetric $\mathrm{N}, \mathrm{N}$-bis(3-aminopropyl)- $N, N$-dialkylammonium iodides (G) and $N, N$-bis-(phthalimidopropyl)- $N, N$-dialkylammonium iodides (F) the average chemical shift of this atom is $57.2 \mathrm{ppm}$. It means that quaternization increases the chemical shifts of carbon atom attached to central nitrogen atom $\left(\mathrm{CH}_{2}-\mathrm{N}\right)$ about 5.4 and $5.8 \mathrm{ppm}$ for asymmetric $N, N$-bis-(3-aminopropyl)- $N, N$-dialkylammonium iodides (G) and $N, N$-bis-(phthalimidopropyl)- $N, N$-dialkylammonium iodides (F), respectively. However for symmetric $N, N$-bis-(3-aminopropyl)- $N, N$-dialkylammonium iodides (G10-G15) the average value of chemical shift is $52.0 \mathrm{ppm}$, i.e. the similar value of chemical shifts for free base. The differences between chemical shifts of $\mathrm{CH}_{2}-\mathrm{N}$ carbon in symmetric and asymmetric $N, N$-bis-(3-aminopropyl)$N, N$-dialkylammonium iodides (G) indicates that not only electron effects have a contribution to deshielding of carbon atoms but also structural and anisotropic factors are important.

A study of norspermidine derivatives by the electron impact (EI) mass spectrometry method has been stimulated by its suitability for distinction of positional isomers-peripheral or central nitrogen atoms. The main characteristics of the EI MS ionization of the norspermidine derivatives is the dependence of the fragmentation pathways on the stability of the formed ions. The EI mass spectrometry fragmentation pathways of these compounds is analytically useful. The formed in a reproducible way fragment ions are specific fingerprint of norspermidine derivatives [34]. In all EI-MS spectra, the molecular ion $\left[\mathbf{M}^{+} \cdot \mathbf{a}\right]$ is present. In the $N, N$-bis-(phtalimidopropyl)- $N$-propylamine (Chart 8, Scheme 2) the peak of molecular ion a $\left[\mathrm{C}_{25} \mathrm{H}_{27} \mathrm{~N}_{3} \mathrm{O}_{4}\right]^{++}$is observed at $\mathrm{m} / \mathrm{z} 433(10 \%)$.

Elimination from molecular ion $\mathrm{C}_{2} \mathrm{H}_{5}$ or $\mathrm{C}_{16} \mathrm{H}_{21} \mathrm{~N}_{2} \mathrm{O}_{2}$. radicals lead to even electron $\left(\mathrm{EE}^{+}\right)$ions $\mathbf{b}$ and $\mathbf{g}$, respectively. The simple cleavage of $\mathrm{Nsp}^{2}-\mathrm{Csp}^{3}$ bond from molecular ion of $N, N$-bis-(phtalimidopropyl)- $N$-propylamine gave fragmentary ion $\mathrm{c}$ situated at $\mathrm{m} / \mathrm{z} 272$. Subsequently elimination of $\mathrm{C}_{2} \mathrm{H}_{3}$. lead to $\mathrm{EE}^{+}$ ion $\mathrm{d}$ situated at $\mathrm{m} / \mathrm{z} 214$ (100\% relative intensity). Even electron ion $\mathbf{e}$ is formed 


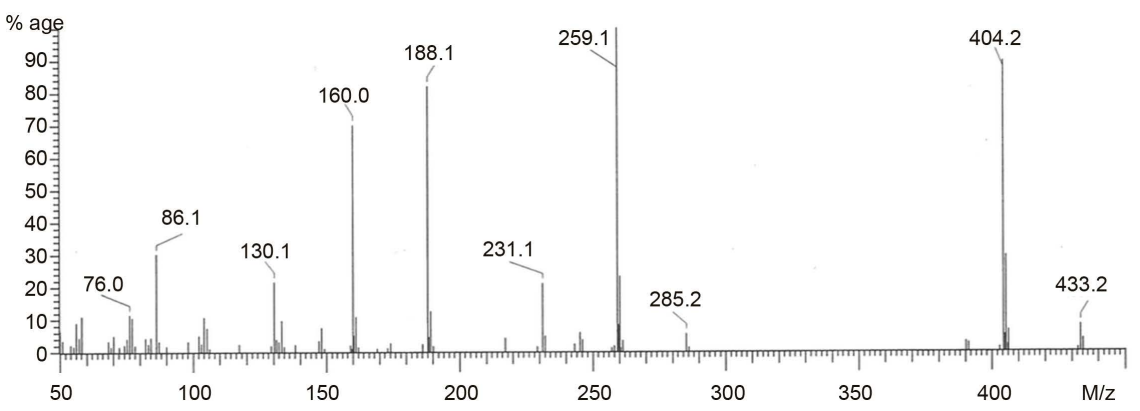

Chart 8. EI-MS spectrum for $N, N$-bis-(phthalimidopropyl)- $N$-propylamine (B2).

by elimination radicals $\mathrm{C}_{19} \mathrm{H}_{7} \mathrm{NO}_{2} \cdot$ or $\mathrm{C}_{2} \mathrm{H}_{4} \cdot$ and rearrangement of proton from ions $\mathbf{b}$ and $\mathbf{d}$, respectively. The inductive cleavage of $\mathrm{Csp}^{3}-\mathrm{Nsp}^{3}$ bond and rearrangement of proton from $\mathrm{EE}^{+}$ion $\mathbf{e}$ give ion $\mathbf{f}(86 \%)$.

The relative intensities of fragmented ions of $N, N$-bis-(phtalimidopropyl)$-N, N$-didodecylammonium iodide were very low with the exception of three ions situated at $\mathrm{m} / \mathrm{z} 728$ (100\%), 188 (38\%) and 160 (24\%) (Chart 9). The ions situated at $\mathrm{m} / \mathrm{z} 188$ and $\mathrm{m} / \mathrm{z} 160$ have the structures of ions $\mathbf{f}$ and $\mathbf{g}$ from Scheme 2. The ion with $\mathrm{m} / \mathrm{z}$ at 728 was very intense because of presence of a quaternary nitrogen atom in the molecule.

\subsection{Antimicrobial Activity}

Some of norspermidine derivatives, especially those containing quaternary nitrogen atoms and long alkyl chain can act as microbiocides, i.e. compounds which can reduce the microbial population to safe level. To microbiocides belong phenols and their derivatives, organic and inorganic halogen compounds, oxidizing substances, quaternary ammonium compounds, alcohols, aldehydes and organic and inorganic acids [35]-[40]. One of the most important group of microbiocides are quaternary ammonium compounds (QAC) because of their wide spectrum of biocidal activity, the safety of application and low costs. This group includes, among the others, alkylbenzyldimethylammonium chlorides, tetraalkylammonium chlorides, dialkyldimethylammonium iodides and gemini surfactants [35]-[45]. The mechanism of action of ammonium salts is related to the adsorption of the compound on the negatively charged cell wall, and the perforation following the discharge of low molecular weight intracellular components and also involves the reaction of enzymes and nucleoprotein systems, which ultimately leads to the death of microorganism cell. The highest antimicrobial activity is observed for quaternary ammonium compounds (QAC) with alkyl chain containing 10 - 14 carbon atoms what is due to the ability to penetrate cell wall [35]. The main drawback of the use of quaternary ammonium salts is the ability of microorganisms to adapt to these compounds after a long time of the use of these compounds as microbiocides. One of the way to avoid this problem is a periodic change of the structure of quaternary ammonium compounds.

In our preliminary studies we found that polyamines, such as $N, N$-bis-(3aminopropyl)- $N$-dodecylamine, exhibit a very good biocidal activity [46]. It has 


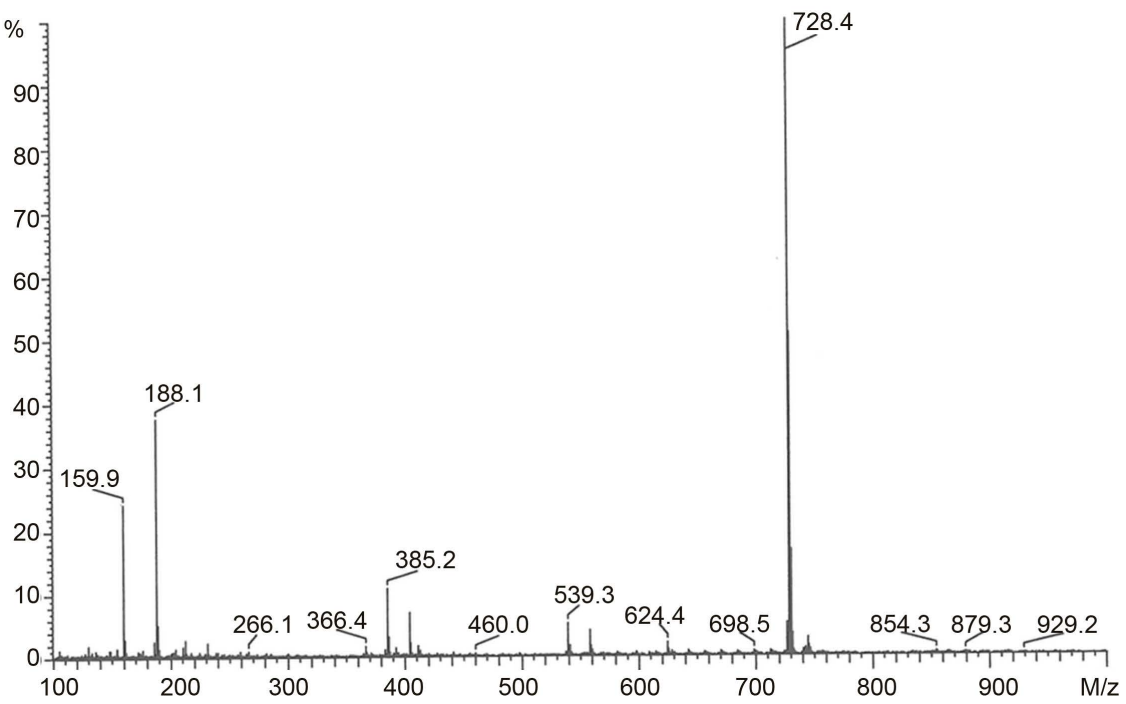

Chart 9. EI-MS spectrum for $N, N$-bis-(phthalimidopropyl)- $N, N$-didodecylammonium iodide (F14).

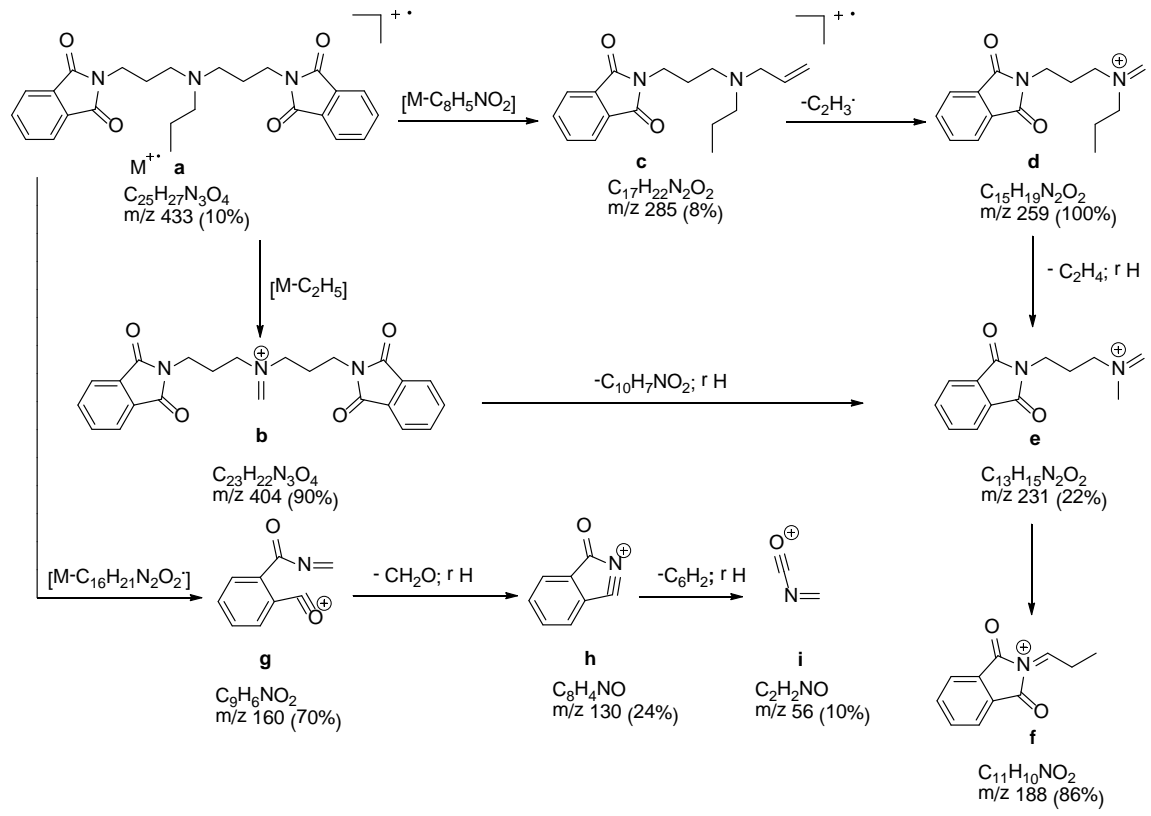

Scheme 2. Pathways of the EI mass fragmentation of $N, N$-bis-(phtalimidopropyl)$N$-propylamine.

been also shown that this compound reduces population of Pseudomonas aeruginosa, Staphylococcus aureus and Escherichia hirae above $99.99 \%$ at $0.05 \%$ during $5 \mathrm{~min}$. [47]. Therefore the idea was to get together alkylamine moiety with ammonium moiety to obtain new kind of amineammonium salt with good antimicrobial activity.

Norspermidine dialkyl derivatives, i.e. $N, N$-bis-(3-aminopropyl)- $N, N$-dialkylammonium iodides (G) are combination of $N, N$-bis-(3-aminopropyl)- $N$-alkylamines (F) and alkyl aliphatic chain to give quaternary ammonium salts which can possess a significant biocidal activity and inhibit a raising resistance of mi- 
croorganism to microbiocides permanently used. The microbial activity of three $N, N$-bis-(3-aminopropyl)- $N, N$-dialkylammonium iodides (G), i.e. $N, N$-bis-(3aminopropyl)- $N$-butyl- $N$-propylammonium iodide (G3), $N, N$-bis-(3-aminopropyl)- $N$-dodecyl- $N$-propylammonium iodide (G7) and the $N, N$-bis-(3 aminopropyl)- $N, N$-didodecyloammonium iodide (G14) have been tested against Gram-negative and Gram-positive bacteria-Staphylococcus aureus and Escherichia coli, as well as against fungi-Candida albicans and Aspergillus niger. The above compounds with different alkyl chains have been choosen to check the effect of structure on antimicrobial activity. In this stage minimal inhibitory concentration of quaternary norspermidine derivatives against bacteria and microscopic fungi (yeast and moulds) were measured. The MICs are defined as the lowest concentration of the compounds at which there was no visible growth of microorganisms. MIC values were determined by a tube standard 2-fold dilution method as it has been described previously [45]. Minimal inhibitory concentrations (MIC) of investigated norspermidine derivatives are given in Table 2.

The data in Table 2 clearly indicate the strong effect of norspermidine derivative structure on antimicrobial activity. Norspermidine derivative with two short alkyl chain, $N, N$-bis-(3-aminopropyl)- $N$-butyl- $N$-propyl iodide (G3), show antimicrobial efficacy (MIC) at $32 \mu \mathrm{M}$ and $38 \mu \mathrm{M}$ against Staphylococcus aureus and Escherichia coli, respectively. When one alkyl chain is lengthened to twelve carbon atoms in $N, N$-bis-(3-aminopropyl)- $N$-dodecyl- $N$-propylammonium iodide (G7), then MIC values decreases to $0.8 \mu \mathrm{M}$ in case of $S$. aureus and to 1.1 $\mu \mathrm{M}$ in case of $E$. coli. This compound is also very active against fungi, showing MIC values at $16 \mu \mathrm{M}$ and $26 \mu \mathrm{M}$ for Candida albicans and Aspergillus niger, respectively (Table 2). However, the norspermidine derivative with two dodecyl alkyl chain (G14) is much more effective then (G7). MIC values for compound with two dodecyl alkyl chains (G14) decrease to $3.2 \mu \mathrm{M}$ and $2.6 \mu \mathrm{M}$ for $C$. albicans and $A$. niger, respectively.Relative antimicrobial activity of $N, N$-bis-(3aminopropyl)- $N, N$-dialkylammonium iodides (G3, G7, G14) against bacteria and fungi are given in Table 3.

The lengthening of one alkyl chain to twelve carbon atoms causes an increase of anitibacterial activity several dozens. Similarly the extending of both alkyl chains to twelve methylene groups effectively enhances antifungal activity of norspermidine derivatives. The above results confirm the strong relationship

Table 2. Antimicrobial properties (MIC) of selected $N, N$-bis-(3-aminopropyl)- $N, N$ dialkyl-ammonium iodides (G3, G7, G14).

\begin{tabular}{ccccc}
\hline \multirow{2}{*}{$\begin{array}{c}\text { Compounds } \\
\text { symbol }\end{array}$} & $\begin{array}{c}\text { Staphylococcus } \\
\text { aureus }\end{array}$ & $\begin{array}{c}\text { Escherichia } \\
\text { coli }\end{array}$ & $\begin{array}{c}\text { Candida } \\
\text { albicans }\end{array}$ & $\begin{array}{c}\text { Aspergillus } \\
\text { niger }\end{array}$ \\
\cline { 2 - 5 } G3 & 32 & 38 & ne & ne \\
G7 & 0.8 & 1.1 & 16 & 26 \\
G14 & ne & ne & 3.2 & 2.6 \\
\hline
\end{tabular}

${ }^{*}$ MIC (minimal inhibitory concentration); ne-not examined. 
Table 3. Relative antimicrobial activity of $N, N$-bis-(3-aminopropyl)- $N, N$-dialkylammonium iodides (G3, G7, G14).

\begin{tabular}{ccc}
\hline Microorganisms & $\mathrm{C}_{3} \mathrm{C}_{12}{ }^{*} / \mathrm{C}_{3} \mathrm{C}_{4}^{* *}$ & $\mathrm{C}_{12} \mathrm{C}_{12}{ }^{* *} / \mathrm{C}_{3} \mathrm{C}_{12}{ }^{*}$ \\
\hline Staphylococcus aureus & 40 & ne \\
Escherichia coli & 35 & ne \\
Candida albicans & ne & 10 \\
Aspergillus niger & ne & 5 \\
\hline
\end{tabular}

${ }^{*} \mathrm{C}_{3} \mathrm{C}_{12} N, N$-bis-(3-aminopropyl)- $N$-dodecyl- $N$-propylammonium iodide (G7). ${ }^{* *} \mathrm{C}_{3} \mathrm{C}_{4} N, N$-bis-(3-amino-propyl)- $N$-butyl- $N$-propylammonium iodide(G3). ${ }^{* *} \mathrm{C}_{12} \mathrm{C}_{12} N, N$-bis-(3-aminopropyl)- $N, N$-didodecylammonium iodide (G14), ne-not examined.

between structure of norspermidine quaternary derivatives and antibacterial and antifungal activity. The longer alkyl substituent facilitate permeating the cell wall thus the biocidal activity of dodecyl derivatives is much higher then another ones. The results of antimicrobial activity of norspermidine derivatives are comparable with those given in literature for $N, N$-dodecyl- $N, N$-dimethyl ammonium chloride [35] [48]. The study of cell viability for Pseudomonas aeruginosa, Escherichia coli and Staphylococcus aureus for the most active compounds of alkyl and phthalimide derivatives of norspermidine are in progress.

\section{Conclusion}

A series of new norspermidine derivatives were obtained with good yields. All new compounds were characterized by spectral methods. Detailed assignments of proton and carbon chemical shifts have been made by 2D NMR spectroscopy. The length of alkyl substituent has negligible effect on proton and carbon chemical shifts in ${ }^{1} \mathrm{H}$ and ${ }^{13} \mathrm{C}$ NMR both in neutral and cationic derivatives. Quaternization of central nitrogen atom of norspermidine cause observable chemical shifts both proton and carbons of methylene spacer, especially those directly attached to nitrogen atom. No shift effect is observed at carbonyl carbon of phthalimide moiety. EI mass spectrometry fragmentation pathways of phthalimide derivatives have been discussed to exploit it as an analytical tool. FTIR spectra of hydrochloride derivatives show bands due to the intermolecular hydrogen bond. Position and intensity of these bands reflect electron donor properties of alkyl substituent at central nitrogen atom. Novel norspermidine derivatives, $N, N$-bis-(3-aminopropyl)- $N, N$-dialkylammonium iodides, exhibit a very good antimicrobial activity which strongly depends on the length of alkyl substituent.

\section{References}

[1] Leeuwenhoek, A. (1678) De natis e semine genital animalculis. Philosophical Transactions, 12, 1040-1046. https://doi.org/10.1098/rstl.1677.0068

[2] Michael, A.J. (2016) Polyamines in Eukaryotes, Bacteria, and Archaea. The Journal of Biological Chemistry, 291, 14896-14903. https://doi.org/10.1074/jbc.R116.734780

[3] Hamana, K., Furuchi, T., Nakamura, T., Hayashi, H. and Niitsu, M. (2016) Occur- 
rence of Penta-Amines, Hexa-Amines and $N$-Methylated Polyamines in Unicellular Eukaryotic Organisms Belonging to the Phyla Heterokontophyta and Labyrinthulomycota of the Subdomain Stramenopiles. The Journal of General and Applied Microbiology, 62, 320-325. https://doi.org/10.2323/jgam.2016.05.001

[4] Liu, Q., Nishibori, N., Imai, I. and Hollibaugh, J.T. (2016) Response of Polyamine Pools in Marine Phytoplankton to Nutrient Limitation and Variation in Temperature and Salinity. Marine Ecology Progress Series, 544, 93-105. https://doi.org/10.3354/meps11583

[5] Silva, T.M., Andersson, S., Sukumaran, S.K., Marques, M.P., Persson, L. and Oredsson, S. (2013) Norspermidine and Novel Pd(II) and Pt(II) Polynuclear Complexes of Norspermidine as Potential Antineoplastic Agents against Breast Cancer. Plos One, 8, e55651. https://doi.org/10.1371/journal.pone.0055651

[6] Karatan, E. and Michael, A.J. (2013) A Wider Role for Polyamines in Biofilm Formation. Biotechnology Letters, 35, 1715-1717.

https://doi.org/10.1007/s10529-013-1286-3

[7] Kostakioti, M., Hadjifrangiskou, M. and Hultgren, S.J. (2013) Bacterial Biofilms: Developments, Dispersal, and Therapeutic Strategies in the Dawn of the Postantibiotic Area. Cold Spring Harbor Perspectives in Medicine, 3, 1-23.

https://doi.org/10.1101/cshperspect.a010306

[8] Dang, H. and Lovell, C.R. (2016) Microbial Surface Colonization and Biofilm Development in Marine Environments, Microbiology and Molecular Biology Reviews, 80, 91-138. https://doi.org/10.1128/MMBR.00037-15

[9] Costerton, J.W., Stewart, P.S. and Greenberg, E.P. (1999) Bacterial Biofilms: A Common Cause of Persistent Infections. Science, 284, 1318-1322. https://doi.org/10.1126/science.284.5418.1318

[10] Wu, Y.C., Quan, X.C., Si, X.R. and Wang, X.R. (2016) A Small Molecule Norspermidine in Combination with Silver Ion Enhances Dispersal and Disinfection of Multi-Species Wastewater Biofilms. Applied Microbiology and Biotechnology, 100, 5619-5629. https://doi.org/10.1007/s00253-016-7394-y

[11] Ou, M. and Ling, J. (2017) Norspermidine Changes the Basic Structure of $S$. mutans Biofilm. Molecular Medicine Reports, 15, 210-220.

[12] Qu, L., She, P., Wang, Y., Liu, F., Zhang, D., Chen, L., Luo, Z., Xu, H., Qi, Y. and Wu, Y. (2016) Effects of Norspermidine on Pseudomonas aeruginosa, Biofilm Formation and Eradication. Microbiology Open, 5, 402-412.

https://doi.org/10.1002/mbo3.338

[13] Payne, S.M., Mey, A.R. and Wyckoff, E.E. (2016) Vibrio Iron Transport: Evolutionary Adaptation to Life in Multiple Environments. Microbiology and Molecular Biology Reviews, 80, 69-90. https://doi.org/10.1128/MMBR.00046-15

[14] Ramon-Perez, M.L., Diaz-Cedillo, F., Contreraz-Rodriguez, A., Betanzos-Cabrera, G., Peralta, H., Rodriguez-Martinez, S., Cancino-Diaz, M.E., Jan-Roblero, J. and Cancino-Diaz, J.C. (2015) Different Sensivity Levels to Norspermidine on Biofilm Formation in Clinical and Commensal Staphylococcus epidermidis Strains. Microbial Pathogenesis, 79, 8-16. https://doi.org/10.1016/j.micpath.2014.12.004

[15] Oppenheimer-Shaanan, Y., Steinberg, N. and Kolodkin-Gal, I. (2013) Small Molecules Are Natural Triggers for the Disassembly of Biofilms. Trends in Microbiology, 21, 594-601. https://doi.org/10.1016/j.tim.2013.08.005

[16] Leiman, S.A., May, J.M., Lebar, M.D., Kolter, R. and Losick, R. (2013) D-Amino Acids Indirectly Inhibit Biofim Formation in Bacillus subtilis by Interfering with Protein Synthesis. Journal of Bacteriology, 195, 5391-5395.

https://doi.org/10.1128/JB.00975-13 
[17] Hobley, L., Kim, S.H., Maezato, Y., Wyllie, S., Fairlamb, A.H. and Stanley-Walt, N.R. (2014) Norspermidine Is Not a Self-Produced Trigger for Biofim Disassembly. Cell, 156, 844-854. https://doi.org/10.1016/j.cell.2014.01.012

[18] Kolodkin-Gal, I., Cao, S., Chai, L., Böttcher, T., Kolter, R., Clardy, J. and Losick, R. (2012) A Self-Produced Trigger for Biofilm Disassembly That Targets Expolysaccharide. Cell, 149, 684-692. https://doi.org/10.1016/j.cell.2012.02.055

[19] Si, X., Quan, X., Li, Q. and Wu, Y. (2014) Effects of D-Amino Acids and Norspermidine on the Disassembly of Large, Old-Aged Microbial Aggregates. Water Research, 54, 247-253. https://doi.org/10.1016/j.watres.2014.02.007

[20] Konai, M.M., Ghosh, C., Yarlagadda, V. and Samaddar, S. (2014) Membrane Active Phenylalanine Conjugated Lipophilic Norspermidine Derivatives with Selective Antibacterial Activity. Journal of Medicinal Chemistry, 57, 9409-9423. https://doi.org/10.1021/jm5013566

[21] Wang, Y., Kim, S.H., Natarajan, R., Heindl, J.E., Bruger, E.L., Waters, C.M., Michael, A.J. and Fuqua, C. (2016) Spermidine Inversely Influences Surface Interactions and Planktonic Growth in Agrobacterium tumefaciens. Journal of Bacteriolo$g y, 198,2682-2691$. https://doi.org/10.1128/JB.00265-16

[22] Brycki, B., Kowalczyk, I., Werner, J., Borowiak, T. and Wolska, I. (2006) Polyamines. I. Spectroscopic Properties of $N, N$-bis-(phtalimidopropyl)- $N$-propylamine and Supramolecular Interactions in Its Crystals. Journal of Molecular Structure, 791, 137-143. https://doi.org/10.1016/j.molstruc.2006.01.023

[23] Brycki, B., Werner, J., Kowalczyk, I., Borowiak, T. and Wolska, I. (2010) Polyamines. III. Spectroscopic properties of $N, N$-bis-(phthalimidopropyl)- $N$-octylamine and Supramolecular Interactions in Its Crystals. Journal of Molecular Structure, 967, 34-41. https://doi.org/10.1016/j.molstruc.2009.12.034

[24] National Industrial Chemicals Notification and Assessment Scheme, Lonzabac 12.100, Full Public Repport, Australia, 16 December 1992.

[25] Abacilar, M., Daus, F., Haas, Ch., Brückner, S.I., Brunner, E. and Geyer, A. (2016) Synthesis and NMR Analysis of ${ }^{13} \mathrm{C}$ and ${ }^{15} \mathrm{~N}$-Labeled Long-Chain Polyamines (LCPAs). RSC Advances, 6, 93343-93348. https://doi.org/10.1039/C6RA19624A

[26] Haussener, T.J., Sebahar, P.R., Kanna Reddy, H.R., Williams, D.L. and Looper, R.E. (2016) A Practical Synthesis of $N$-alkyl- and $N, N$-dialkyl-polyamines. Tetrahedron Letters, 57, 2845-2848. https://doi.org/10.1016/j.tetlet.2016.05.034

[27] Silverstein, R.M., Webster F.X., Kiemle D.J. and Bryce D.L. (2015) Spectrometric Identification of Organic Compounds. 8th Edition, John Wiley \& Sons, Ltd. Chichester, 230-298.

[28] Friebolin, H. (2011) Basic One- and Two-Dimensional NMR Spectroscopy. 5th Edition, Wiley-VCH, Weinheim.

[29] Field, L.D., Li, H.L. and Magill, A.M. (2015) Organic Structures from 2D NMR Spectra. John Wiley \& Sons, Ltd., Chichester.

[30] Simpson, H. (2008) Organic Structure Determination Using 2-D NMR Spectroscopy. Academic Press Elsevier, London.

[31] Barrett, D.M.Y., Kahwa, I.A., Mague, J.T. and McPherson, G.L. (1995) Preparations, Crystal Structures, and Unusual Proton NMR Characteristics of Some Phthalimides. Journal of Organic Chemistry, 60, 5946-5953. https://doi.org/10.1021/jo00123a035

[32] Howell, R.C., Edwards, S.H., Gajadhar-Plummer, A.S., Kahwa, I.A., McPherson, G.L., Mague, J.T., White, A.J.P. and Williams, D.J. (2003) Phthalimides: Supramolecular Interactions in Crystals, Hypersensitive Solution ${ }^{1} \mathrm{H}-\mathrm{NMR}$ Dynamics and Energy Transfer to Europium(III) and Terbium(III) States. Molecules, 8, 565-592. 
https://doi.org/10.3390/molecules8070565

[33] Grzesiak, W. and Brycki, B. (2012) Synthesis, FTIR, ${ }^{13} \mathrm{C}$ NMR and TemperatureDependent ${ }^{1} \mathrm{H}$ NMR Characteristics of Bis-Naphthalimide Derivatives. Molecules, 17, 12427-12448. https://doi.org/10.3390/molecules171012427

[34] Watson, J.T. and Sparkman, O.D. (2009) Introduction to Mass Spectrometry. Instrumentation, Applications and Strategies for Data Interpretation. John Wiley \& Sons, Ltd., Chichester, 315-449.

[35] Block, S.S. (2001) Disinfection, Sterilization, and Preservation. 5th Edition, Lippincott Williams and Wilkins, Philadelphia.

[36] Wallhäußer, K.H. (1995) Praxis der Sterilization Desinfektio-Konservierung, Auflage, Georg ThiemeVerlag, Stuttgart.

[37] Fraise, A.P., Maillard, J.-Y. and Sattar, S.A. (2013) Russell, Hugo \& Ayliffe's Principles and Practice of Disinfection, Preservation \& Sterilization. 5th Edition, Wiley-Blackwell, Chichester. https://doi.org/10.1002/9781118425831

[38] Manivannan, G. (2008) Disinfection and Decontamination; Principles, Applications and Related Issues. CRC Press Taylor \& Francis Group, Boca Raton.

[39] Paulus, W. (2005) Directory of Microbiocides for the Protection of Materials. A. Handbook, Springer, Dordrecht. https://doi.org/10.1007/1-4020-2818-0

[40] Stanga, M. (2010) Sanitation. Cleaning and Disinfection in the Food Industry. Wiley-VCH GmbH\&Co. KGaA, Weinheim.

[41] Cross, J. and Singer, E.J. (1994) Cationic Surfactants, Analytical and Biological Evaluation. Marcel Dekker, New York.

[42] Brycki, B. (2010) Gemini Alkylammonium Salts as Biodeterioration Inhibitors. Polish Journal of Microbiology, 59, 227-231.

[43] Karbowska-Berent, J., Kozielec, T., Jarmiłko, J. and Brycki, B. (2011) Possible Application of Quaternary Ammonium Salts for Disinfection of Paper Based Objects. Restaurator-International Journal for the Preservation of Library and Archival Material, 32, 223-246.

[44] Brycki, B. and Szulc, A. (2014) Gemini Alkyldeoxy-D-Glucitolammonium Salts as Modern Surfactants and Microbiocides: Synthesis, Antimicrobial and Surface Activity, Biodegradation. PLoS ONE, 9, e84936.

https://doi.org/10.1371/journal.pone.0084936

[45] Brycki, B., Kowalczyk, I. and Koziróg, A. (2011) Synthesis, Molecular Structure, Spectral Properties and Antifungal Activity of Polymethylene- $\alpha, \omega$-bis $(N, N$-dimethyl- $N$-dodecyloammonium bromides). Molecules, 16, 319-335. https://doi.org/10.3390/molecules16010319

[46] Koziróg, A., Kuberski, S., Żakowska, Z. and Brycki, B. (2005) Influence of N,N-bis(3-aminopropyl)- $N$-dodecylamine on the Mycelium Growth and the Cell Wall Composition of Resistance and Sensitive Strains Belonging to the Genus Aspergillus. Polish Journal of Microbiology, 54, 271-278.

[47] Lonzabac 12.100 for Disinfection, Lonza Bulletin, TSS Europe, March 2013.

[48] Brycki, B., Małecka, I., Koziróg, A. and Otlewska, A. (2017) Synthesis, Structure and Antimicrobial Properties of Novel Benzalkonium Chloride Analogues with Pyridine Rings. Molecules, 22, 130. https://doi.org/10.3390/molecules22010130 


\section{Supplementary Material}

Table S1. Carbonyl range in FTIR for $N, N$-bis-(phthalimidopropyl)amine (A), $N, N$-bis(phthalimidopropyl)- $N$-alkylamines (B1-B11) and for $N, N, N$-tris-(phthalimidopropyl) amine (B12).

\begin{tabular}{cccccc}
\hline Symbol & $\mathrm{R}$ & \multicolumn{2}{c}{$v_{\mathrm{as}}(\mathrm{C}=\mathrm{O})\left[\mathrm{cm}^{-1}\right]$} & $v_{\mathrm{s}}(\mathrm{C}=\mathrm{O})\left[\mathrm{cm}^{-1}\right]$ \\
\hline A & $\mathrm{H}-$ & 1773 & - & 1714 & - \\
B1 & $\mathrm{C}_{2} \mathrm{H}_{5^{-}}$ & 1772 & 1764 & 1714 & - \\
B2 & $\mathrm{C}_{3} \mathrm{H}_{7^{-}}$ & 1771 & 1764 & 1710 & - \\
B3 & $\mathrm{C}_{4} \mathrm{H}_{9^{-}}$ & - & 1765 & 1720 & 1707 \\
B4 & $\mathrm{C}_{5} \mathrm{H}_{11^{-}}$ & - & 1767 & 1718 & 1707 \\
B5 & $\mathrm{C}_{6} \mathrm{H}_{13^{-}}$ & - & 1767 & 1719 & 1707 \\
B6 & $\mathrm{C}_{8} \mathrm{H}_{17^{-}}$ & 1771 & - & - & 1704 \\
B7 & $\mathrm{C}_{10} \mathrm{H}_{21^{-}}$ & 1771 & - & - & 1704 \\
B8 & $\mathrm{C}_{12} \mathrm{H}_{25^{-}}$ & 1773 & 1765 & 1722 & 1706 \\
B9 & $\mathrm{C}_{14} \mathrm{H}_{29^{-}}$ & 1773 & 1766 & 1722 & 1706 \\
B10 & $\mathrm{C}_{16} \mathrm{H}_{33^{-}}$ & 1773 & 1765 & 1723 & 1707 \\
B11 & $\mathrm{C}_{18} \mathrm{H}_{37^{-}}$ & 1773 & 1767 & 1724 & 1707 \\
B12 & $\mathrm{C}_{11} \mathrm{H}_{10} \mathrm{NO}_{2-}$ & 1771 & - & 1711 & - \\
\hline
\end{tabular}

* phthalimide substituent.

Table S2. Carbonyl range in FTIR for $N, N$-bis-(phthalimidopropyl)ammonium hydrochloride (C), $N, N$-bis-(phthalimidopropyl)- $N$-alkylammonium hydrochlorides (D1-D11) and $N, N, N$-tris-(phthalimidopropyl)ammonium hydrochloride (D12).

\begin{tabular}{ccccc}
\hline Symbol & $\mathrm{R}$ & $v_{\text {as }}(\mathrm{C}=\mathrm{O})\left[\mathrm{cm}^{-1}\right]$ & $v_{\mathrm{s}}(\mathrm{C}=\mathrm{O})\left[\mathrm{cm}^{-1}\right]$ & $\mathrm{N}-\mathrm{H}^{\cdots} \mathrm{Cl}^{-}\left[\mathrm{cm}^{-1}\right]$ \\
\hline C & $\mathrm{H}-$ & 1768 & 1698 & 2789 \\
D1 & $\mathrm{C}_{2} \mathrm{H}_{5^{-}}$ & 1771 & 1701 & 2420 \\
D2 & $\mathrm{C}_{3} \mathrm{H}_{7^{-}}$ & 1767 & 1700 & 2414 \\
D3 & $\mathrm{C}_{4} \mathrm{H}_{9^{-}}$ & 1767 & 1700 & 2459 \\
D4 & $\mathrm{C}_{5} \mathrm{H}_{11^{-}}$ & 1767 & 1704 & 2383 \\
D5 & $\mathrm{C}_{6} \mathrm{H}_{13^{-}}$ & 1769 & 1704 & 2388 \\
D6 & $\mathrm{C}_{8} \mathrm{H}_{17^{-}}$ & 1770 & 1707 & 2354 \\
D7 & $\mathrm{C}_{10} \mathrm{H}_{21^{-}}$ & 1770 & 1707 & 2355 \\
D8 & $\mathrm{C}_{12} \mathrm{H}_{25^{-}}$ & 1770 & 1707 & 2349 \\
D9 & $\mathrm{C}_{14} \mathrm{H}_{29^{-}}$ & 1774 & 1716 & 2338 \\
D10 & $\mathrm{C}_{16} \mathrm{H}_{33^{-}}$ & 1772 & 1715 & 2454 \\
D11 & $\mathrm{C}_{18} \mathrm{H}_{37^{-}}$ & 1772 & 1705 & 2344 \\
D12 & $\mathrm{C}_{11} \mathrm{H}_{10} \mathrm{NO}_{2^{-}}$ & 1769 & 1702 & 2354 \\
\hline
\end{tabular}

* phthalimide substituent. 
Table S3. The characteristic infrared bands for $N, N$-bis-(3-aminopropyl)-N-alkylamines (E1-E6).

\begin{tabular}{ccccccc}
\hline Symbol & $\mathrm{R}$ & $v_{\text {as }}(\mathrm{N}-\mathrm{H})\left[\mathrm{cm}^{-1}\right]$ & $v_{\mathrm{s}}(\mathrm{N}-\mathrm{H})\left[\mathrm{cm}^{-1}\right]$ & $\delta(\mathrm{N}-\mathrm{H})\left[\mathrm{cm}^{-1}\right] \delta(\mathrm{N}-\mathrm{H})\left[\mathrm{cm}^{-1}\right] v(\mathrm{C}-\mathrm{N})\left[\mathrm{cm}^{-1}\right]$ \\
\hline E1 & $\mathrm{C}_{3} \mathrm{H}_{7^{-}}$ & 3362 & 3285 & 1603 & 819 & 1097 \\
E2 & $\mathrm{C}_{4} \mathrm{H}_{9^{-}}$ & 3362 & 3286 & 1598 & 819 & 1092 \\
E3 & $\mathrm{C}_{8} \mathrm{H}_{17^{-}}$ & 3364 & 3288 & 1599 & 818 & 1091 \\
E4 & $\mathrm{C}_{12} \mathrm{H}_{25^{-}}$ & 3363 & 3285 & 1598 & 825 & 1090 \\
E5 & $\mathrm{C}_{16} \mathrm{H}_{33^{-}}$ & 3364 & 3288 & 1597 & 817 & 1091 \\
E6 & $\mathrm{C}_{18} \mathrm{H}_{37^{-}}$ & 3364 & 3289 & 1597 & 818 & 1090 \\
\hline
\end{tabular}

Table S4. Carbonyl range in FTIR for $N, N$-bis-(phthalimidopropyl)- $N, N$-dialkylammonium iodides (F1-F17).

\begin{tabular}{cccccc}
\hline Symbol & $\mathrm{R}$ & $\mathrm{R}^{\prime}$ & $v_{\text {as }}(\mathrm{C}=\mathrm{O})\left[\mathrm{cm}^{-1}\right]$ & $v_{\mathrm{s}}(\mathrm{C}=\mathrm{O})\left[\mathrm{cm}^{-1}\right]$ \\
\hline F1 & $\mathrm{C}_{3} \mathrm{H}_{7^{-}}$ & $\mathrm{C}_{2} \mathrm{H}_{5^{-}}$ & 1772 & 1703 & - \\
F3 & $\mathrm{C}_{3} \mathrm{H}_{7^{-}}$ & $\mathrm{C}_{4} \mathrm{H}_{9^{-}}$ & 1769 & 1707 & - \\
F5 & $\mathrm{C}_{3} \mathrm{H}_{7^{-}}$ & $\mathrm{C}_{8} \mathrm{H}_{17^{-}}$ & 1772 & 1707 & - \\
F7 & $\mathrm{C}_{3} \mathrm{H}_{7^{-}}$ & $\mathrm{C}_{12} \mathrm{H}_{25^{-}}$ & 1772 & 1708 & - \\
F10 & $\mathrm{C}_{4} \mathrm{H}_{9^{-}}$ & $\mathrm{C}_{4} \mathrm{H}_{9^{-}}$ & 1770 & 1706 & - \\
F14 & $\mathrm{C}_{12} \mathrm{H}_{25^{-}}$ & $\mathrm{C}_{12} \mathrm{H}_{25^{-}}$ & 1771 & 1709 & - \\
F16 & $\mathrm{C}_{8} \mathrm{H}_{17^{-}}$ & $\mathrm{C}_{12} \mathrm{H}_{25^{-}}$ & 1769 & 1717 & 1701 \\
F17 & $\mathrm{C}_{18} \mathrm{H}_{37^{-}}$ & $\mathrm{C}_{12} \mathrm{H}_{25^{-}}$ & 1769 & 1718 & 1701 \\
\hline
\end{tabular}

Table S5. Chemical shifts $(\delta, \mathrm{ppm})$ of protons in ${ }^{1} \mathrm{H}$ NMR spectra for $N, N$-bis(phthalimi-dopropyl)amine (A), $N, N$-bis-(phthalimidopropyl)- $N$-alkylamines (B1-B11) oraz $N, N, N$-tris-(phthalimidopropyl)amine (B12) in $\mathrm{CDCl}_{3}$.

\begin{tabular}{|c|c|c|c|c|c|c|c|c|c|}
\hline Symbol & $\mathbf{R}$ & $a$ & $b, c$ & $d$ & $e$ & $f$ & $g$ & $\boldsymbol{h}$ & $i$ \\
\hline A & $\mathrm{H}-$ & - & - & $1.24^{\star *}$ & 2.63 & 1.84 & 3.75 & 7.82 & 7.72 \\
\hline B1 & $\mathrm{C}_{2} \mathrm{H}_{5^{-}}$ & 0.96 & - & 2.47 & 2.49 & 1.80 & 3.73 & 7.81 & 7.71 \\
\hline B2 & $\mathrm{C}_{3} \mathrm{H}_{7-}$ & 0.88 & 1.40 & 2.36 & 2.49 & 1.80 & 3.74 & 7.82 & 7.71 \\
\hline B3 & $\mathrm{C}_{4} \mathrm{H}_{9-}^{-}$ & 0.88 & 1.31 & 2.38 & 2.48 & 1.80 & 3.73 & 7.82 & 7.71 \\
\hline B4 & $\mathrm{C}_{5} \mathrm{H}_{11^{-}}$ & 0.88 & 1.25 & 2.38 & 2.49 & 1.81 & 3.74 & 7.81 & 7.72 \\
\hline B5 & $\mathrm{C}_{6} \mathrm{H}_{13^{-}}$ & 0.86 & 1.24 & 2.38 & 2.49 & 1.80 & 3.73 & 7.81 & 7.71 \\
\hline B6 & $\mathrm{C}_{8} \mathrm{H}_{17^{-}}$ & 0.87 & 1.24 & 2.37 & 2.48 & 1.80 & 3.73 & 7.82 & 7.71 \\
\hline B7 & $\mathrm{C}_{10} \mathrm{H}_{21^{-}}$ & 0.87 & 1.24 & 2.38 & 2.49 & 1.80 & 3.73 & 7.81 & 7.71 \\
\hline B8 & $\mathrm{C}_{12} \mathrm{H}_{25^{-}}$ & 0.87 & 1.24 & 2.38 & 2.48 & 1.80 & 3.73 & 7.81 & 7.71 \\
\hline B9 & $\mathrm{C}_{14} \mathrm{H}_{29^{-}}$ & 0.88 & 1.25 & 2.38 & 2.48 & 1.80 & 3.73 & 7.81 & 7.71 \\
\hline B10 & $\mathrm{C}_{16} \mathrm{H}_{33^{-}}$ & 0.88 & 1.25 & 2.39 & 2.49 & 1.81 & 3.73 & 7.81 & 7.71 \\
\hline B11 & $\mathrm{C}_{18} \mathrm{H}_{37^{-}}$ & 0.88 & 1.25 & 2.37 & 2.48 & 1.80 & 3.73 & 7.81 & 7.71 \\
\hline B12 & $\mathrm{C}_{12} \mathrm{H}_{11} \mathrm{NO}_{2^{-*}}$ & - & - & - & 2.50 & 1.79 & 3.75 & 7.79 & 7.70 \\
\hline
\end{tabular}

${ }^{*}$ phthalimide substituent. ${ }^{* *}$ signal from the proton attached to the nitrogen atom of the central. 
Table S6. Chemical shifts (ppm) of protons in ${ }^{1} \mathrm{H}$ NMR spectra for $N, N$-bis-(phthalimidopropyl)ammonium hydrochloride (C), $N, N$-bis-(phthalimidopropyl)- $N$-alkylammonium hydrochlorides (D1-D11) and $N, N, N$-tris-(phthalimidopropyl)ammonium hydrochloride (D12) in $\mathrm{CDCl}_{3}$.

\begin{tabular}{|c|c|c|c|c|c|c|c|c|c|c|}
\hline Symbol & $\mathbf{R}$ & $a$ & $b$ & $c$ & $d$ & $e$ & $f$ & $g$ & $\boldsymbol{h}$ & $i$ \\
\hline $\mathrm{C}$ & $\mathrm{H}-$ & - & - & - & - & 3.09 & 2.34 & 3.90 & 7.79 & 7.71 \\
\hline D1 & $\mathrm{C}_{2} \mathrm{H}_{5^{-}}$ & 1.38 & - & - & 2.29 & 3.13 & 2.10 & 3.80 & 7.82 & 7.75 \\
\hline D2 & $\mathrm{C}_{3} \mathrm{H}_{7^{-}}$ & 0.98 & - & 2.98 & 2.28 & 3.14 & 1.85 & 3.80 & 7.82 & 7.76 \\
\hline D3 & $\mathrm{C}_{4} \mathrm{H}_{9^{-}}$ & 0.93 & 1.35 & 3.00 & 2.29 & 3.13 & 1.74 & 3.80 & 7.83 & 7.76 \\
\hline D4 & $\mathrm{C}_{5} \mathrm{H}_{11^{-}}$ & 0.92 & 1.27 & 3.02 & 2.29 & 3.12 & 1.75 & 3.80 & 7.82 & 7.75 \\
\hline Symbol & $\mathrm{R}$ & $\mathrm{a}$ & $\mathrm{b}$ & c & $\mathrm{d}$ & e & $\mathrm{f}$ & $\mathrm{g}$ & $\mathrm{h}$ & $\mathrm{i}$ \\
\hline D5 & $\mathrm{C}_{6} \mathrm{H}_{13^{-}}$ & 0.86 & 1.27 & 3.00 & 2.29 & 3.12 & 1.75 & 3.80 & 7.84 & 7.75 \\
\hline D6 & $\mathrm{C}_{8} \mathrm{H}_{17^{-}}$ & 0.87 & 1.24 & 2.96 & 2.28 & 3.10 & 1.73 & 3.80 & 7.83 & 7.76 \\
\hline D7 & $\mathrm{C}_{10} \mathrm{H}_{21^{-}}$ & 0.87 & 1.24 & 2.97 & 2.28 & 3.08 & 1.73 & 3.80 & 7.83 & 7.76 \\
\hline D8 & $\mathrm{C}_{12} \mathrm{H}_{25^{-}}$ & 0.87 & 1.24 & 2.96 & 2.26 & 3.08 & 1.73 & 3.80 & 7.83 & 7.76 \\
\hline D9 & $\mathrm{C}_{14} \mathrm{H}_{29^{-}}$ & 0.88 & 1.26 & 2.98 & 2.29 & 3.08 & 1.74 & 3.80 & 7.83 & 7.76 \\
\hline D10 & $\mathrm{C}_{16} \mathrm{H}_{33^{-}}$ & 0.88 & 1.26 & 2.97 & 2.27 & 3.08 & 1.69 & 3.80 & 7.84 & 7.77 \\
\hline D11 & $\mathrm{C}_{18} \mathrm{H}_{37^{-}}$ & 0.88 & 1.26 & 2.96 & 2.28 & 3.07 & 1.72 & 3.80 & 7.83 & 7.76 \\
\hline D12 & $\mathrm{C}_{12} \mathrm{H}_{11} \mathrm{NO}_{2^{-*}}$ & - & - & - & - & 3.12 & 2.28 & 3.79 & 7.80 & 7.74 \\
\hline D12 & $\mathrm{C}_{12} \mathrm{H}_{11} \mathrm{NO}_{2^{-*}}$ & - & - & - & - & 3.12 & 2.28 & 3.79 & 7.80 & 7.74 \\
\hline
\end{tabular}

* phthalimide substituent.

Table S7. Chemical shift $\left(\delta\right.$, ppm) of protons in ${ }^{1} \mathrm{H}$ NMR spectra for $N, N$-bis-(3-aminopropyl)amine (Nspd) and $N, N$-bis-(3-aminopropyl)-N-alkylamines (E1-E6) in $\mathrm{CDCl}_{3}$.

\begin{tabular}{|c|c|c|c|c|c|c|c|c|c|}
\hline Symbol & $\mathbf{R}$ & $a$ & $b$ & $c$ & $d$ & $e$ & $f$ & $g$ & $h$ \\
\hline Nspd & H- & - & - & - & $1.15^{\star}$ & 2.66 & 1.62 & 2.75 & 1.15 \\
\hline E1 & $\mathrm{C}_{3} \mathrm{H}_{7^{-}}$ & 0.87 & 1.44 & - & 2.35 & 2.45 & 1.58 & 2.72 & 1.30 \\
\hline E2 & $\mathrm{C}_{4} \mathrm{H}_{9^{-}}$ & 0.88 & 1.41 & 1.28 & 2.36 & 2.45 & 1.59 & 2.72 & 1.26 \\
\hline E3 & $\mathrm{C}_{8} \mathrm{H}_{17^{-}}$ & 0.88 & 1.42 & 1.27 & 2.37 & 2.45 & 1.58 & 2.72 & 1.27 \\
\hline E4 & $\mathrm{C}_{12} \mathrm{H}_{25^{-}}$ & 0.88 & 1.41 & 1.27 & 2.37 & 2.45 & 1.58 & 2.72 & 1.27 \\
\hline E5 & $\mathrm{C}_{16} \mathrm{H}_{33^{-}}$ & 0.88 & 1.42 & 1.26 & 2.38 & 2.45 & 1.59 & 2.72 & 1.26 \\
\hline E6 & $\mathrm{C}_{18} \mathrm{H}_{37^{-}}$ & 0.88 & 1.42 & 1.25 & 2.38 & 2.45 & 1.59 & 2.71 & 1.25 \\
\hline
\end{tabular}

*signal from the proton attached to the nitrogen atom of the central. 
Table S8. Chemical shifts $\left(\delta\right.$, ppm) of protons in ${ }^{1} \mathrm{H}$ NMR spectra for $N, N$-bis-(phthalimidopropyl)- $N, N$-dialkylammonium iodides (F1-F17) and $N, N, N$-tris-(phthalimidopropyl)- $N$-alkylammonium iodides (F18-F19) in $\mathrm{D}_{2} \mathrm{O}$.

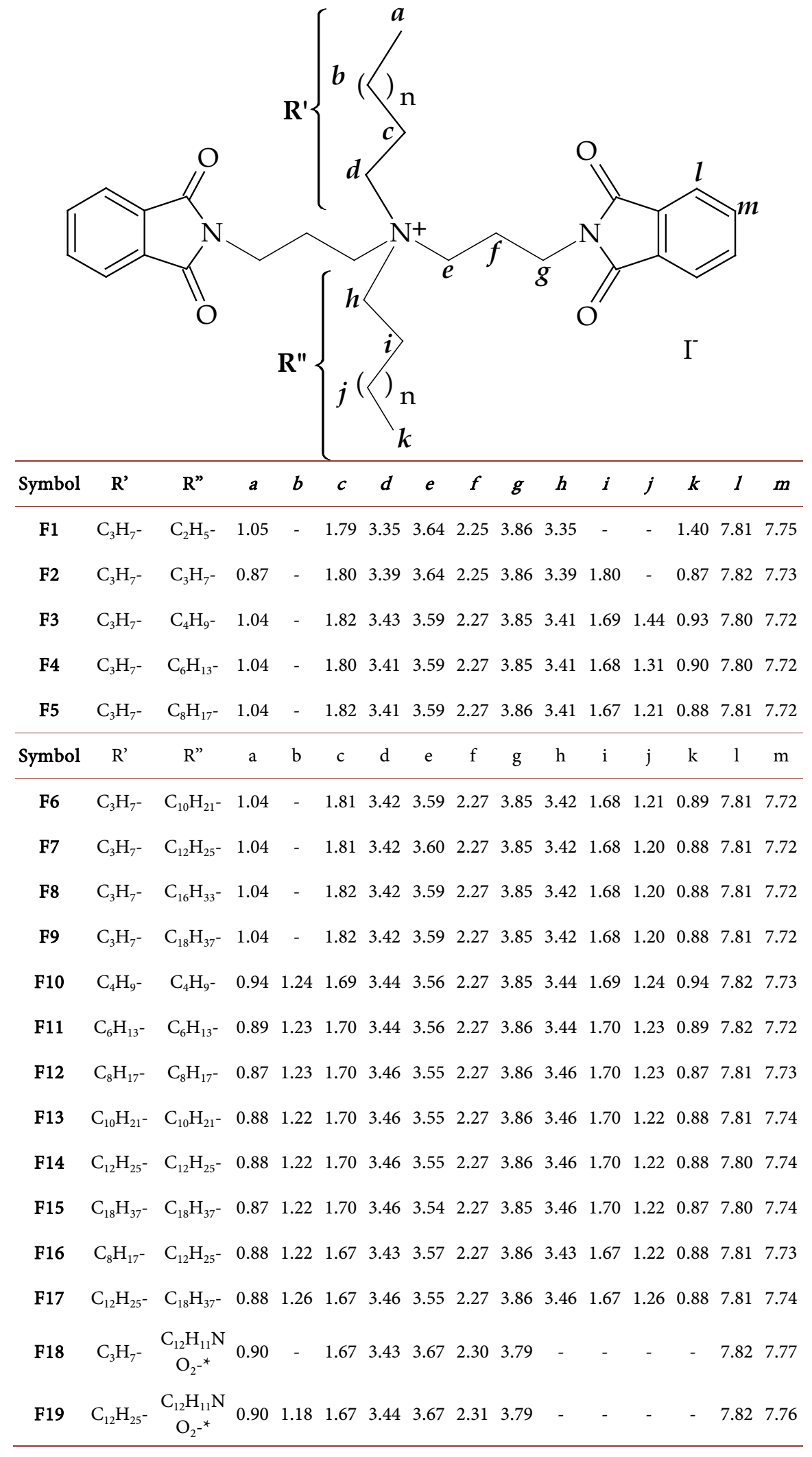

*phthalimide substituent. 
Table S9. Chemical shifts ( $\delta, \mathrm{ppm})$ of protons in ${ }^{1} \mathrm{H}$ NMR spectra for $N, N$-bis-(3-aminopropyl)- $N, N$-dialkyloammonium iodides (G1-G17) in $\mathrm{D}_{2} \mathrm{O}$.

\begin{tabular}{|c|c|c|c|c|c|c|c|c|c|c|c|c|c|}
\hline Symbol & $\mathrm{R}^{\prime}$ & R" & $a$ & $b$ & $c$ & $d$ & $e$ & $f$ & $g$ & $h$ & $i$ & $j$ & $k$ \\
\hline G1 & $\mathrm{C}_{3} \mathrm{H}_{7^{-}}$ & $\mathrm{C}_{2} \mathrm{H}_{5^{-}}$ & 1.00 & - & 1.78 & 3.35 & 3.44 & 2.18 & 3.15 & 3.35 & - & - & 1.38 \\
\hline G2 & $\mathrm{C}_{3} \mathrm{H}_{7^{-}}$ & $\mathrm{C}_{3} \mathrm{H}_{7^{-}}$ & 1.03 & - & 1.78 & 3.32 & 3.44 & 2.18 & 3.16 & 3.35 & 1.78 & - & 1.03 \\
\hline G3 & $\mathrm{C}_{3} \mathrm{H}_{7^{-}}$ & $\mathrm{C}_{4} \mathrm{H}_{9^{-}}$ & 0.97 & - & 1.77 & 3.35 & 3.45 & 2.16 & 3.10 & 3.35 & 1.75 & 1.40 & 0.97 \\
\hline G4 & $\mathrm{C}_{3} \mathrm{H}_{7^{-}}$ & $\mathrm{C}_{6} \mathrm{H}_{13^{-}}$ & 1.05 & - & 1.78 & 3.32 & 3.46 & 2.18 & 3.11 & 3.32 & 1.78 & 1.34 & 0.90 \\
\hline G5 & $\mathrm{C}_{3} \mathrm{H}_{7^{-}}$ & $\mathrm{C}_{8} \mathrm{H}_{17^{-}}$ & 1.05 & - & 1.79 & 3.32 & 3.53 & 2.20 & 3.11 & 3.32 & 1.79 & 1.31 & 0.90 \\
\hline Symbol & $\mathrm{R}^{\prime}$ & $\mathrm{R}^{\prime \prime}$ & $\mathrm{a}$ & b & c & $\mathrm{d}$ & e & $\mathrm{f}$ & g & $\mathrm{h}$ & $\mathrm{i}$ & $\mathrm{j}$ & $\mathrm{k}$ \\
\hline G6 & $\mathrm{C}_{3} \mathrm{H}_{7^{-}}$ & $\mathrm{C}_{10} \mathrm{H}_{21^{-}}$ & 1.05 & - & 1.79 & 3.31 & 3.53 & 2.20 & 3.11 & 3.31 & 1.79 & 1.31 & 0.90 \\
\hline G7 & $\mathrm{C}_{3} \mathrm{H}_{7^{-}}$ & $\mathrm{C}_{12} \mathrm{H}_{25^{-}}$ & 1.05 & - & 1.79 & 3.32 & 3.53 & 2.21 & 3.11 & 3.32 & 1.79 & 1.29 & 0.90 \\
\hline G8 & $\mathrm{C}_{3} \mathrm{H}_{7^{-}}$ & $\mathrm{C}_{16} \mathrm{H}_{33^{-}}$ & 1.05 & - & 1.80 & 3.31 & 3.54 & 2.21 & 3.11 & 3.31 & 1.80 & 1.28 & 0.90 \\
\hline G9 & $\mathrm{C}_{3} \mathrm{H}_{7^{-}}$ & $\mathrm{C}_{18} \mathrm{H}_{37^{-}}$ & 1.05 & - & 1.82 & 3.31 & 3.62 & 2.21 & 3.09 & 3.31 & 1.82 & 1.28 & 0.90 \\
\hline G10 & $\mathrm{C}_{4} \mathrm{H}_{9^{-}}$ & $\mathrm{C}_{4} \mathrm{H}_{9^{-}}$ & 0.97 & 1.39 & 1.77 & 3.36 & 3.46 & 2.16 & 3.12 & 3.35 & 1.69 & 1.39 & 0.97 \\
\hline G11 & $\mathrm{C}_{6} \mathrm{H}_{13^{-}}$ & $\mathrm{C}_{6} \mathrm{H}_{13^{-}}$ & 0.90 & 1.34 & 1.77 & 3.36 & 3.45 & 2.15 & 3.10 & 3.36 & 1.71 & 1.34 & 0.90 \\
\hline G12 & $\mathrm{C}_{8} \mathrm{H}_{17^{-}}$ & $\mathrm{C}_{8} \mathrm{H}_{17^{-}}$ & 0.90 & 1.32 & 1.77 & 3.32 & 3.46 & 2.16 & 3.06 & 3.32 & 1.71 & 1.32 & 0.90 \\
\hline G13 & $\mathrm{C}_{10} \mathrm{H}_{21^{-}}$ & $\mathrm{C}_{10} \mathrm{H}_{21^{-}}$ & 0.89 & 1.26 & 1.79 & 3.31 & 3.46 & 2.16 & 3.05 & 3.31 & 1.79 & 1.28 & 0.89 \\
\hline G14 & $\mathrm{C}_{12} \mathrm{H}_{25^{-}}$ & $\mathrm{C}_{12} \mathrm{H}_{25^{-}}$ & 0.89 & 1.28 & 1.81 & 3.32 & 3.46 & 2.19 & 3.05 & 3.32 & 1.80 & 1.28 & 0.90 \\
\hline G15 & $\mathrm{C}_{18} \mathrm{H}_{37^{-}}$ & $\mathrm{C}_{18} \mathrm{H}_{37^{-}}$ & 0.90 & 1.28 & 1.79 & 3.31 & 3.47 & 2.20 & 3.00 & 3.31 & 1.79 & 1.28 & 0.90 \\
\hline G16 & $\mathrm{C}_{8} \mathrm{H}_{17^{-}}$ & $\mathrm{C}_{12} \mathrm{H}_{25^{-}}$ & 0.90 & 1.28 & 1.77 & 3.31 & 3.47 & 2.20 & 3.01 & 3.31 & 1.79 & 1.29 & 0.90 \\
\hline G17 & $\mathrm{C}_{12} \mathrm{H}_{25^{-}}$ & $\mathrm{C}_{18} \mathrm{H}_{37^{-}}$ & 0.90 & 1.28 & 1.77 & 3.32 & 3.40 & 2.20 & 3.11 & 3.32 & 1.77 & 1.28 & 0.90 \\
\hline
\end{tabular}


Table S10. Chemical shifts $(\delta, \mathrm{ppm})$ of carbon atoms in ${ }^{13} \mathrm{C}$ NMR spectra for $N, N$-bis(phthalimidopropyl)amine (A), $N, N$-bis-(phthalimidopropyl)- $N$-alkylamines (B1-B11) and $N, N, N$-tris-(phthalimidopropyl)amine (B12) in $\mathrm{CDCl}_{3}$.<smiles>[R]CCCN(CCCN1C(=O)c2ccccc2C1=O)CC(C)C=CCC</smiles>

\begin{tabular}{|c|c|c|c|c|c|c|c|c|c|c|c|c|}
\hline Symbol & $\mathbf{R}$ & $a$ & $b$ & $c$ & $d$ & $e$ & $f$ & $g$ & $h$ & $i$ & $j$ & $k$ \\
\hline A & $\mathrm{H}-$ & - & - & - & - & 46.9 & 28.9 & 35.9 & 168.51 & 132.1 & 133.91 & 123.2 \\
\hline B1 & $\mathrm{C}_{2} \mathrm{H}_{5^{-}}$ & 11.5 & - & - & 50.9 & 46.9 & 26.3 & 36.5 & 168.11 & 132.1 & 133.61 & 123.0 \\
\hline B2 & $\mathrm{C}_{3} \mathrm{H}_{7^{-}}$ & 11.9 & 20.1 & - & 55.6 & 51.5 & 26.3 & 36.5 & 168.41 & 132.2 & 133.81 & 123.1 \\
\hline B3 & $\mathrm{C}_{4} \mathrm{H}_{9^{-}}$ & 14.1 & 20.6 & 29.1 & 53.4 & 51.4 & 26.2 & 36.5 & 168.41 & 132.2 & 133.81 & 123.1 \\
\hline Symbol & $\mathrm{R}$ & $\mathrm{a}$ & $\mathrm{b}$ & c & d & e & $\mathrm{f}$ & g & $\mathrm{h}$ & $\mathrm{i}$ & j & $\mathrm{k}$ \\
\hline B4 & $\mathrm{C}_{5} \mathrm{H}_{11^{-}}$ & 14.1 & 22.7 & $26.9,35.6$ & 53.5 & 51.4 & 26.1 & 36.5 & 168.41 & 132.2 & 133.81 & 123.1 \\
\hline B5 & $\mathrm{C}_{6} \mathrm{H}_{13^{-}}$ & 14.2 & 22.7 & $26.9,27.2,31.9$ & 53.7 & 51.5 & 26.3 & 36.6 & 168.21 & 132.1 & 133.71 & 123.0 \\
\hline B6 & $\mathrm{C}_{8} \mathrm{H}_{17^{-}}$ & 14.1 & 22.7 & $\begin{array}{c}26.9,27.5,29.3 \\
29.6,31.9\end{array}$ & 53.7 & 51.4 & 26.2 & 36.5 & 168.41 & 132.2 & 133.81 & 123.1 \\
\hline B7 & $\mathrm{C}_{10} \mathrm{H}_{21^{-}}$ & 14.2 & 22.7 & $\begin{array}{c}26.9,27.6,29.4 \\
29.7,31.9\end{array}$ & 53.7 & 51.5 & 26.3 & 36.5 & 168.21 & 132.1 & 133.61 & 123.0 \\
\hline B8 & $\mathrm{C}_{12} \mathrm{H}_{25^{-}}$ & 14.2 & 22.7 & $\begin{array}{c}26.9,27.6,29.3 \\
29.6,31.9\end{array}$ & 53.8 & 51.5 & 26.3 & 36.6 & 168.21 & 132.2 & 133.81 & 123.1 \\
\hline B9 & $\mathrm{C}_{14} \mathrm{H}_{29^{-}}$ & 14.1 & 22.7 & $\begin{array}{c}26.9,27.5,29.3 \\
29.6,31.9\end{array}$ & 53.7 & 51.4 & 26.2 & 36.5 & 168.31 & 132.2 & 133.71 & 123.1 \\
\hline B10 & $\mathrm{C}_{16} \mathrm{H}_{33^{-}}$ & 14.1 & 22.7 & $\begin{array}{l}26.9,27.5,29.3 \\
29.6,29.7,31.9\end{array}$ & 53.7 & 51.4 & 26.2 & 36.5 & 168.21 & 132.1 & 133.71 & 123.1 \\
\hline B11 & $\mathrm{C}_{18} \mathrm{H}_{37^{-}}$ & 14.1 & 22.7 & $\begin{array}{l}26.9,27.5,29.3 \\
29.6,29.7,31.9\end{array}$ & 53.7 & 51.4 & 26.2 & 36.5 & 168.41 & 132.2 & 133.71 & 123.1 \\
\hline B12 & $\begin{array}{c}\mathrm{C}_{12} \mathrm{H}_{11} \mathrm{~N} \\
\mathrm{O}_{2^{-*}}\end{array}$ & - & - & - & - & 51.2 & 26.1 & 36.3 & 168.31 & 132.2 & 133.71 & 123.1 \\
\hline
\end{tabular}


Table S11. Chemical shifts $(\delta, \mathrm{ppm})$ of arbon atoms in ${ }^{13} \mathrm{C}$ NMR spectra for $N, N$-bis(phthalimidopropyl)ammonium hydrochloride (C), N,N-bis-(phthalimidopropyl)-Nalkylammonium hydrochlorides (D1-D11) and $N, N, N$-tris-(phthalimidopropyl)ammonium hydrochloride (D12) in $\mathrm{CDCl}_{3}$.

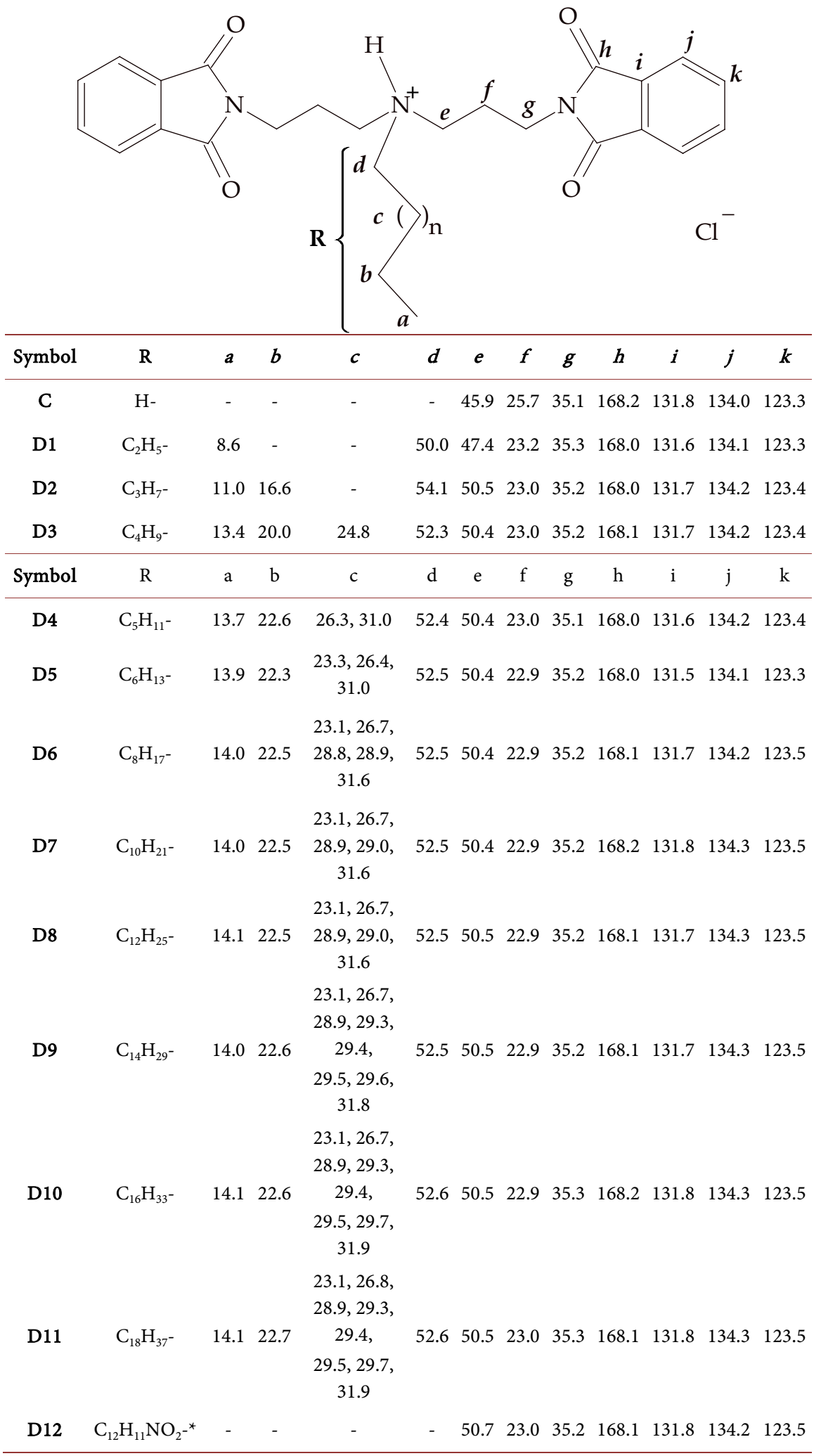

*phthalimide substituent. 
Table S12. Chemical shifts $\left(\delta\right.$, ppm) of carbon atoms in ${ }^{13} \mathrm{C}$ NMR spectra for $N, N$-bis-(3aminopropyl)amine (Nspd) and $N, N$-bis-(3-aminopropyl)- $N$-alkylamines (E1-E6) in $\mathrm{CDCl}_{3}$.

\begin{tabular}{|c|c|c|c|c|c|c|c|c|}
\hline Symbol & $\mathbf{R}$ & $a$ & $b$ & $c$ & $d$ & $e$ & $f$ & $g$ \\
\hline Nspd & $\mathrm{H}-$ & - & - & - & - & 47.0 & 33.0 & 39.6 \\
\hline E1 & $\mathrm{C}_{3} \mathrm{H}_{7^{-}}$ & 11.8 & 20.0 & - & 55.9 & 51.7 & 30.9 & 40.6 \\
\hline E2 & $\mathrm{C}_{4} \mathrm{H}_{9^{-}}$ & 14.1 & 20.7 & 31.0 & 54.5 & 51.6 & 30.9 & 40.4 \\
\hline E3 & $\mathrm{C}_{8} \mathrm{H}_{17^{-}}$ & 14.1 & 22.6 & $\begin{array}{c}26.8,27.6,29.5 \\
29.6,30.3\end{array}$ & 54.0 & 51.8 & 31.4 & 40.4 \\
\hline E4 & $\mathrm{C}_{12} \mathrm{H}_{25^{-}}$ & 14.2 & 22.7 & $\begin{array}{c}26.6,27.2,28.9 \\
29.2,30.6\end{array}$ & 54.1 & 51.9 & 32.0 & 40.6 \\
\hline E5 & $\mathrm{C}_{16} \mathrm{H}_{33^{-}}$ & 14.2 & 22.7 & $\begin{array}{c}26.6,27.0,29.4 \\
29.7,31.0\end{array}$ & 54.2 & 51.9 & 32.0 & 40.8 \\
\hline E6 & $\mathrm{C}_{18} \mathrm{H}_{37^{-}}$ & 14.2 & 22.8 & $\begin{array}{c}26.8,27.2,29.5 \\
29.7,31.0\end{array}$ & 54.2 & 52.0 & 32.0 & 40.8 \\
\hline
\end{tabular}

Table S13. Chemical shifts $(\delta, \mathrm{ppm})$ of carbon atoms in ${ }^{13} \mathrm{C}$ NMR spectra for $N, N$-bis-(phthalimidopropyl)- $N, N$-dialkylammonium iodides (F1-F17) and $N, N, N$-tris-(phthalimidopropyl)- $N$-alkylammonium iodides (F18-F19) in $\mathrm{D}_{2} \mathrm{O}$.

\begin{tabular}{|c|c|c|c|c|c|c|c|c|c|c|c|c|c|c|c|c|}
\hline & $\mathrm{R}^{\prime}$ & R" & $a$ & $b, j$ & $c$ & $d$ & $e$ & $f$ & $g$ & $h$ & $i$ & $k$ & 1 & $m$ & $n$ & $o$ \\
\hline F1 & $\mathrm{C}_{3} \mathrm{H}_{7^{-}}$ & $\mathrm{C}_{2} \mathrm{H}_{5^{-}}$ & 10.8 & - & 16.0 & 60.7 & 55.6 & 22.0 & 35.1 & 56.8 & - & 8.5 & 168.2 & 131.6 & 134.3 & 123.4 \\
\hline F2 & $\mathrm{C}_{3} \mathrm{H}_{7^{-}}$ & $\mathrm{C}_{3} \mathrm{H}_{7^{-}}$ & 10.8 & - & 16.2 & 61.4 & 55.2 & 22.1 & 35.1 & 57.4 & 16.2 & 10.8 & 168.2 & 131.7 & 134.4 & 123.5 \\
\hline F3 & $\mathrm{C}_{3} \mathrm{H}_{7^{-}}$ & $\mathrm{C}_{4} \mathrm{H}_{9^{-}}$ & 10.8 & 19.6 & 16.1 & 61.3 & 57.2 & 22.0 & 35.1 & 59.7 & 24.2 & 13.6 & 168.1 & 131.5 & 134.3 & 123.4 \\
\hline F4 & $\mathrm{C}_{3} \mathrm{H}_{7^{-}}$ & $\mathrm{C}_{6} \mathrm{H}_{13^{-}}$ & 10.8 & $21.5,22.3,31.0$ & 16.1 & 61.3 & 57.3 & 22.4 & 35.2 & 59.7 & 26.4 & 13.9 & 168.0 & 131.5 & 134.2 & 123.4 \\
\hline F5 & $\mathrm{C}_{3} \mathrm{H}_{7^{-}}$ & $\mathrm{C}_{8} \mathrm{H}_{17^{-}}$ & 10.8 & $\begin{array}{c}21.6,22.2,29.0 \\
29.1,31.6\end{array}$ & 16.1 & 61.3 & 57.2 & 22.6 & 35.2 & 59.8 & 26.4 & 14.1 & 168.0 & 131.5 & 134.2 & 123.4 \\
\hline F6 & $\mathrm{C}_{3} \mathrm{H}_{7^{-}}$ & $\mathrm{C}_{10} \mathrm{H}_{21^{-}}$ & 10.8 & $\begin{array}{c}21.9,22.3 \\
29.0-29.2,29.5 \\
31.7\end{array}$ & 16.2 & 61.3 & 57.2 & 22.6 & 35.1 & 59.7 & 26.4 & 14.0 & 168.1 & 131.5 & 134.2 & 123.4 \\
\hline F7 & $\mathrm{C}_{3} \mathrm{H}_{7^{-}}$ & $\mathrm{C}_{12} \mathrm{H}_{25^{-}}$ & 10.8 & $\begin{array}{c}21.9,22.3,29.0- \\
29.5,31.7\end{array}$ & 16.1 & 61.3 & 57.2 & 22.6 & 35.0 & 59.8 & 26.3 & 14.0 & 168.1 & 131.5 & 134.2 & 123.3 \\
\hline
\end{tabular}




\section{Continued}

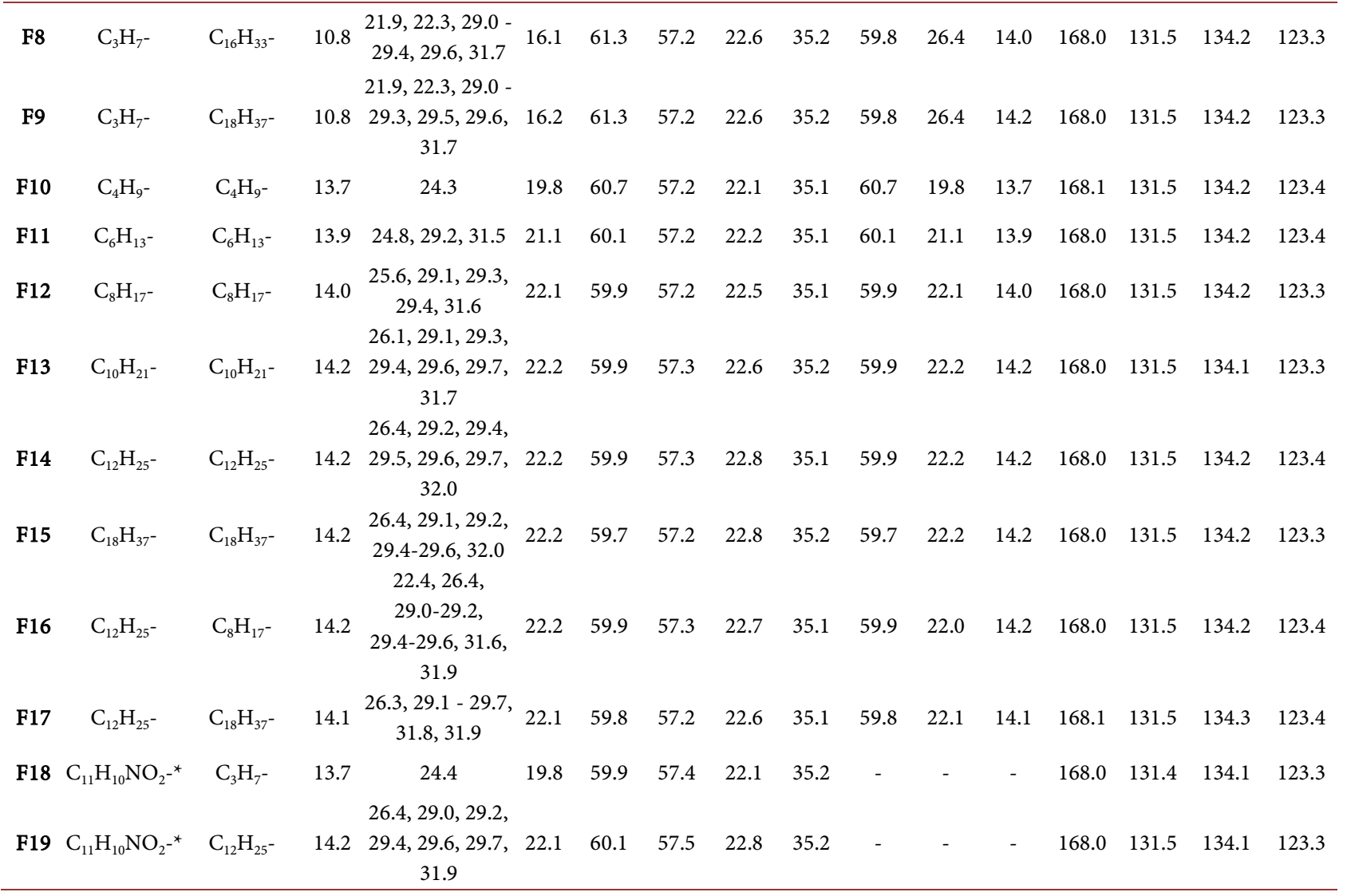

Table S14. Chemical shifs $(\delta, \mathrm{ppm})$ of carbon atoms in ${ }^{13} \mathrm{C}$ NMR spectra for $N, N$-bis-(3-aminopropyl)- $N, N$-dialkylammonium iodides (G1-G17) in $\mathrm{D}_{2} \mathrm{O}$.

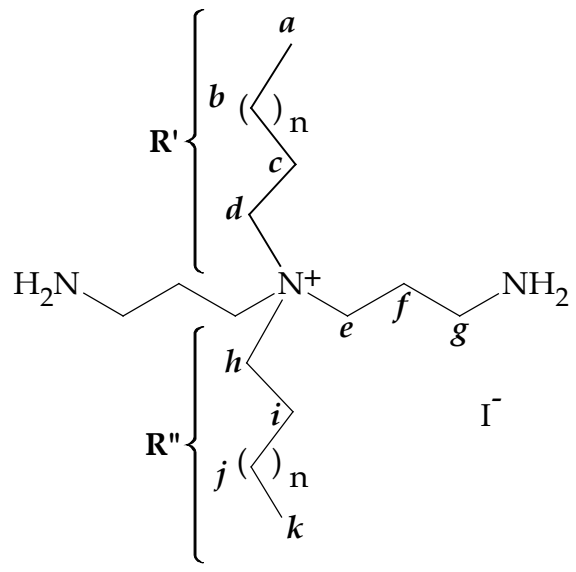

\begin{tabular}{|c|c|c|c|c|c|c|c|c|c|c|c|c|}
\hline Symbol & $\mathbf{R}^{\prime}$ & R" & $a$ & $b, j$ & $c$ & $d$ & $e$ & $f$ & $g$ & $\boldsymbol{h}$ & $i$ & $k$ \\
\hline G1 & $\mathrm{C}_{3} \mathrm{H}_{7^{-}}$ & $\mathrm{C}_{2} \mathrm{H}_{5^{-}}$ & 10.0 & - & 17.9 & 63.0 & 49.0 & 22.5 & 39.0 & 57.5 & - & 12.5 \\
\hline G2 & $\mathrm{C}_{3} \mathrm{H}_{7^{-}}$ & $\mathrm{C}_{3} \mathrm{H}_{7^{-}}$ & 11.4 & - & 20.7 & 62.1 & 51.2 & 23.2 & 38.0 & 62.1 & 20.7 & 11.4 \\
\hline G3 & $\mathrm{C}_{3} \mathrm{H}_{7^{-}}$ & $\mathrm{C}_{4} \mathrm{H}_{9^{-}}$ & 12.7 & 17.9 & 22.8 & 63.4 & 58.3 & 26.1 & 39.2 & 62.0 & 21.9 & 15.7 \\
\hline G4 & $\mathrm{C}_{3} \mathrm{H}_{7^{-}}$ & $\mathrm{C}_{6} \mathrm{H}_{13^{-}}$ & 11.5 & $17.0,22.2,30.9$ & 23.6 & 63.2 & 57.5 & 26.4 & 38.5 & 61.8 & 23.4 & 14.9 \\
\hline G5 & $\mathrm{C}_{3} \mathrm{H}_{7^{-}}$ & $\mathrm{C}_{8} \mathrm{H}_{17^{-}}$ & 11.1 & $\begin{array}{c}17.0,21.8,30.3,30.4 \\
30.6,30.7\end{array}$ & 23.7 & 62.1 & 57.2 & 27.5 & 37.8 & 60.7 & 23.2 & 14.6 \\
\hline
\end{tabular}




\section{Continued}

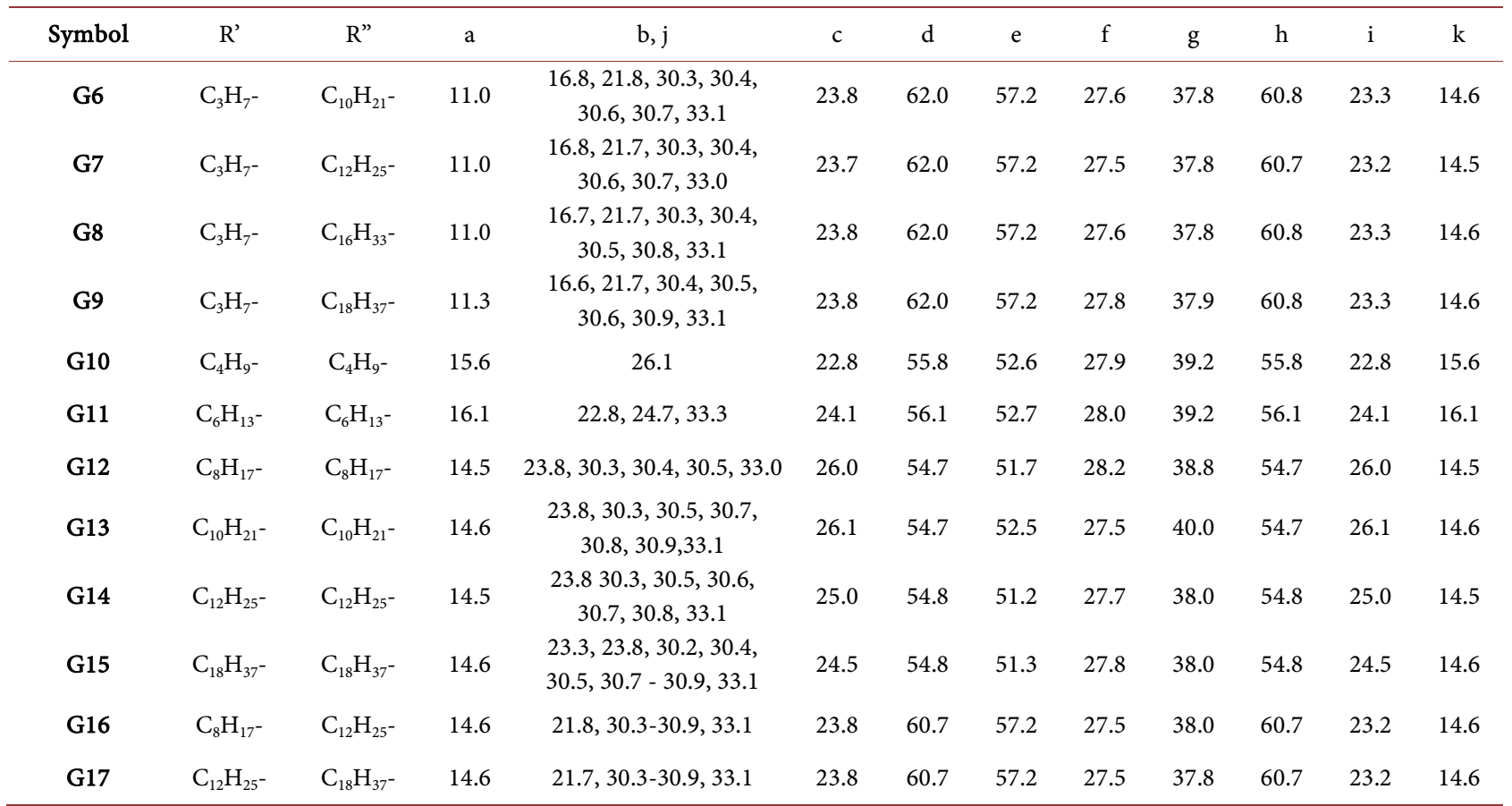

Submit or recommend next manuscript to SCIRP and we will provide best service for you:

Accepting pre-submission inquiries through Email, Facebook, LinkedIn, Twitter, etc. A wide selection of journals (inclusive of 9 subjects, more than 200 journals)

Providing 24-hour high-quality service

User-friendly online submission system

Fair and swift peer-review system

Efficient typesetting and proofreading procedure

Display of the result of downloads and visits, as well as the number of cited articles

Maximum dissemination of your research work

Submit your manuscript at: http://papersubmission.scirp.org/

Or contact ijoc@scirp.org 